\title{
Life history traits of the fish community in Lake Annecy: evidence from the stable isotope composition of otoliths
}

\author{
D. Gerdeaux ${ }^{(1), \star}$, E. Dufour ${ }^{(2)}$
}

Received September 13, 2015

Revised October 30, 2015

Accepted October 31, 2015

\section{ABSTRACT}

Key-words: stable isotopes, oxygen, carbon, temperature, metabolism
Stable isotope analysis (SIA) of fish otoliths shows great potential for exploring the ecology of fish, but this method has not been applied to the study of lacustrine fish communities. Both sequential and whole-otolith SIAs were performed on six fish species of Lake Annecy and their results compared to muscle SIA. The first purpose of these investigations was to test the use of $\delta^{18} \mathrm{O}_{\text {oto }}$ values for reconstructing fish thermal history and delimiting spatial distribution in a stratified lake. Comparison of speciesspecific fractionation equations and the general equation developed for freshwater fishes showed that the general one was the best suited for thermal estimation of Lake Annecy fishes and suggested that inter-specific differences or specific "vital effects" are not the only reason for apparent difference in fractionation. Thermal estimations based on SIA were consistent with descriptions of thermal habitats in the literature, except in the case of roach (Rutilus rutilus). Based on the current results, roach appears to live in a colder habitat than do perch (Perca fluviatilis). The high water transparency and thermal stratification of Lake Annecy could explain this distribution. Moreover, perch juveniles were found to live in two different thermal niches. This finding highlights the great plasticity of the species. Second, the potential use of $\delta^{13} \mathrm{C}_{\text {oto }}$ values to reconstruct variation in diet and metabolism was assessed. The proportion of metabolic carbon $(M)$ contributing to otolith carbon varies markedly among species. Comparison with $\delta^{13} \mathrm{C}_{\text {muscle }}$ values shows no direct relationship between $\delta^{13} \mathrm{C}_{\text {oto }}$ and diet at either the intra-individual or the inter-specific level. A strong linear relationship between either $M$ or the isotopic offset between otolith and muscle $\left(\Delta \delta^{13} \mathrm{C}_{\text {oto-muscle }}\right)$ and $\delta^{18} \mathrm{O}_{\text {oto }}$ values was found; this relationship reveals the dependence of $M$ on the ambient temperature at which the species occurs. This relationship might be general and could be used to explore variation in fish metabolism in the future.

\section{RÉSUMÉ}

Traits d'histoire de vie de la communauté de poissons dans le lac d'Annecy : l'apport de la composition en isotopes stables des otolithes

Mots-clés : L'analyse des isotopes stables (SIA) des otolithes de poissons montre un grand isotopes stables, potentiel pour explorer l'écologie des poissons, mais cette méthode n'a encore jamais été appliquée à l'étude des communautés de poissons lacustres. Les SIA séquentielles et globales d'otolithe ont été réalisées sur six espèces de poissons du lac d'Annecy et leurs résultats comparés aux SIA du muscle. Le premier objectif

(1) INRA, UMR CARRTEL, 8 route Tully, 74200 Thonon-les-Bains, France

(2) Archéozoologie, archéobotanique : Sociétés, pratiques et environnements (UMR 7209), Sorbonne

Universités, Muséum national d'histoire naturelle, CNRS, CP55 ou 56, 55 rue Buffon, 75005 Paris, France 
oxygène, carbone, temperature, métabolisme de ces investigations était de tester l'utilisation de valeurs $\delta^{18} \mathrm{O}_{\text {oto }}$ pour reconstruire I'histoire thermique des poissons et préciser leur distribution spatiale dans ce lac stratifié. La comparaison des équations de fractionnement spécifiquement développées pour une espèce et l'équation générale pour les poissons d'eau douce a montré que l'équation générale était la plus adéquate pour l'estimation de l'histoire thermique des poissons du lac d'Annecy. II est également suggéré que des différences inter-spécifiques ou « effets vitaux » spécifiques n'expliquent pas complètement la différence apparente de fractionnement isotopique. Les estimations thermiques basées sur la SIA étaient compatibles avec les descriptions des habitats thermiques dans la littérature, sauf dans le cas du gardon (Rutilus rutilus). Selon les résultats de l'étude, le gardon semble vivre dans un habitat plus froid que celui de la perche (Perca fluviatilis). La grande transparence de l'eau et la stratification thermique du lac d'Annecy pourraient expliquer cette répartition. En outre, les jeunes perches occupaient deux niches thermiques différentes ce qui met en évidence la grande plasticité de l'espèce. Deuxièmement, l'utilisation potentielle des valeurs $\delta^{13} C_{\text {oto }}$ pour reconstruire les variations de l'alimentation et du métabolisme a été évaluée. La proportion de carbone métabolique $(M)$ contribuant au carbone de l'otolithe varie considérablement entre les espèces. La comparaison avec les valeurs $\delta^{13} \mathrm{C}_{\text {muscle }}$ montre qu'il n'y a pas de relation directe entre $\delta^{13} \mathrm{C}_{\text {oto }}$ et le régime alimentaire, ni au niveau intra-individuel, ni au niveau inter-spécifique. Une forte relation linéaire entre soit $\mathrm{M}$, soit la différence isotopique en carbone entre l'otolithe et le muscle ( $\Delta \delta^{13} \mathrm{C}_{\text {oto-muscle }}$ ) et les valeurs $\delta^{18} \mathrm{O}_{\text {oto }}$ a été trouvée; cette relation montre que la valeur de $M$ est fortement dépendante de la température ambiante à laquelle vit l'espèce. Cette relation pourrait être générale et utilisée pour explorer la variation du métabolisme des poissons dans l'avenir.

\section{INTRODUCTION}

Stable isotope analysis (SIA) has enjoyed great success in ecological studies for the past three decades (Michener and Lajtha, 2007). SIA is widely used for studying the ecological characteristics of fishes, including geographical distribution and origin, movements and migrations, trophic interactions, population dynamics and biomagnifications of contaminants (Deutsch and Berth, 2006; Dufour and Gerdeaux, 2001; Hoeinghaus and Zeug, 2008; Jardine et al., 2013). Various fish tissues can be analysed, but soft tissue, generally muscle, has typically been preferred. It is easy to collect and prepare material and it provides the means to analyse several isotopic tracers $\left(\delta^{13} \mathrm{C}, \delta^{15} \mathrm{~N}, \delta^{18} \mathrm{O}, \delta^{34} \mathrm{~S}\right)$.

However, isotope turn-over in fish muscle is low, and somatic growth is usually discontinuous. Muscle SIA primarily reflects the food consumed during the season of rapid growth (Perga and Gerdeaux, 2005) and the reconstruction of ontogenetic shifts in diet or in habitat (Bergman and Greenberg, 1994; Werner and Gilliam, 1984) requires repeated fish sampling and analysis over time. SIA of otoliths has recently become of increasing interest in fish ecology studies. Otoliths are paired calcified $\left(\mathrm{CaCO}_{3}\right)$ structures, usually consisting of aragonite (Degens et al., 1969). Their incremental growth and permanent nature theoretically provides a continuous time series of a fish's environment during the entire life span of the individual (Campana, 1999). Developments in micrometric sampling techniques associated with classical mass spectrometry or in situ SIA have enabled the retrospective reconstruction of the complexity of life chronology (Aubert et al., 2012; Hanson et al., 2010; Wurster et al., 1999). Oxygen and carbon isotopes in otoliths $\left(\delta^{18} \mathrm{O}_{\text {oto }}\right.$ and $\left.\delta^{13} \mathrm{C}_{\text {oto }}\right)$ provide records of the ambient water conditions and the metabolic parameters of the fish. The temperature-dependent fractionation between otolith aragonite and ambient water has been used to reconstruct the thermal histories of fish based on information on the $\delta^{18} \mathrm{O}$ value of water $\left(\delta^{18} \mathrm{O}_{\text {water }}\right)$ and the use of a valid temperature fractionation equation (Patterson et al., 1993; Hoie et al., 2004). Records

\footnotetext{
* Corresponding author: dgerdeaux@wanadoo.fr
} 
of $\delta^{18} \mathrm{O}_{\text {oto }}$, usually in combination with $\delta^{13} \mathrm{C}_{\text {oto }}$, have been used to delineate fish habitat, define stock structure and track fish movements, migrations or depth positioning (Carpenter et al., 2003; Dufour et al., 2007; Huxham et al., 2007; Thorrold et al., 2001) when the various habitats present distinctive physicochemical compositions (temperature, salinity, $\delta^{18} \mathrm{O}_{\text {water }}$ values) or are thermally stratified. Carbon isotopes are deposited under circumstances where they are not at equilibrium with the dissolved inorganic carbon (DIC, $\left.\delta^{13} \mathrm{C}_{\mathrm{DIC}}\right)$ present in the water. Ambient DIC carbon mixes with metabolic carbon $\left(\delta^{13} C_{\text {meta }}\right)$ derived from food (Kalish, 1991; Schwarcz et al., 1998; Tohse and Mugiya, 2002). Variations in $\delta^{13} \mathrm{C}_{\text {oto }}$ have been argued to reflect a host of parameters: standard and active metabolism, diet, trophic position, DIC and depth (Schwarcz et al., 1998). Furthermore, the $\delta^{13} \mathrm{C}_{\text {oto }}$ value of otoliths is correlated with the specific respiration rate of individual fish estimated with $\delta^{18} \mathrm{O}_{\text {oto }}$ values (Dufour et al., 2007; Solomon et al., 2006; Wurster and Patterson, 2003). These values have been used to track ontogenetic changes in diet, trophic level over life or temperature habitat of different morphs of a species (Jamieson et al., 2004; Schwarcz, et al., 1998; Kahilainen et al., 2014). However, applications have been restricted due to uncertainties regarding the nature of the relationship with controlling parameters (Dufour et al., 2007).

Previous otolith SIAs have primarily provided records resolving environmental and behavioural dynamics. Most otolith SIAs have quantified individual variability or change over time in a population or have compared different populations or stocks of a single species (Jamieson et al., 2004; Sako et al., 2007; Weidman and Miller, 2000; Wurster et al., 2005). To our knowledge, the present study is the only research to compare $\delta^{18} \mathrm{O}_{\text {oto }}$ values among several species, and no study has been performed with the specific purpose of comparing the records of life history traits of various species of a fish community. This paper presents SIAs of the principal species of the fish community in Lake Annecy, a deep stratified lake located in the French Alpine region (Haute-Savoie). The first aim of the study was to explore the potential use of $\delta^{18} \mathrm{O}_{\text {oto }}$ values to reconstruct fish thermal histories and delimit spatial distributions within the fish community: are the thermal habitats estimated from $\delta^{18} \mathrm{O}_{\text {oto }}$ consistent with the known vertical positions of the different species? The second aim of the study was to explore the potential use of $\delta^{13} \mathrm{C}_{\text {oto }}$ values to reconstruct both intra-individual and inter-specific variations in diet and metabolism: does the fraction of metabolic carbon in the otolith differ among the species? Is there a relationship between this carbon fraction and the temperatures at which the fish live?

\section{MATERIALS AND METHODS}

\section{> STUDY SITE}

Lake Annecy, France, is at $446 \mathrm{~m}$ a.s.I. and is situated $50 \mathrm{~km}$ south of Lake Geneva. Lake Annecy is of glacial origin, with steep banks and a relatively flat bottom, a surface area of 2800 hectares, and a maximum depth of $65 \mathrm{~m}$. The length and maximum width are 15 and 4 $\mathrm{km}$, respectively. The physical, chemical and biological characteristics of the lake have been under monthly or bi-monthly monitoring for more than a decade (Dufour and Gerdeaux, 2007; Gerdeaux and Perga, 2006). Lake Annecy is monomictic and oligo-mesotrophic, with a total phosphorus concentration that has never exceeded $10 \mu \mathrm{g} \cdot \mathrm{L}^{-1}$. The Lake Annecy mean winter water temperature is between 4.5 and $6{ }^{\circ} \mathrm{C}$. In summer, the thermocline is situated at approximately $15 \mathrm{~m}$ depth, and the hypolimnion temperature remains at $\sim 5^{\circ} \mathrm{C}$. Epilimnion temperatures vary according to depth and exhibit regular seasonal variations. Maximum temperatures, around $22{ }^{\circ} \mathrm{C}$, are encountered in August (Dufour and Gerdeaux, 2007; Dufour et al., 2007; Gerdeaux and Dufour, 2012).

\section{> FISH SPECIES SELECTION AND COLLECTION}

We sampled the principal species of the fish community of Lake Annecy. The Lake Annecy fish community is primarily composed of salmonids, which represent more than $80 \%$ of the 
yield of the fishery in Lake Annecy. Whitefish (Coregonus lavaretus, Linné, 1758) and Arctic char (Salvelinus alpinus, Linné, 1758) are the main species whereas brown trout (Salmo trutta, Linné, 1758) are less well represented. Northern pike (Esox lucius, Linné, 1758) and perch (Perca fluviatilis, Linné, 1758) represent $10 \%$ of the yield. Burbot (Lota lota, Linné, 1758) and certain cyprinids, along with roach (Rutilus rutilus, Linné, 1758) and tench (Tinca tinca, Linné, 1758) represent the remaining $10 \%$ of the total catch (Gerdeaux et al., 2001).

For this study, six species were chosen that present distinctive trophic habits and habitat selection (Appendix 1). In the lake Annecy, Arctic char and whitefish are pelagic cold-water species, whereas roach, perch, Northern pike and tench are inshore warm-water eurythermic species. Northern pike is a top predator feeding primarily on fish. Whitefish is mainly zooplanktivorous and feed opportunistically on chironomids when these invertebrates rise to the surface to moult into adults. Arctic char feeds on benthic invertebrates and sometimes on fish. Roach and tench are omnivorous, as are juvenile perch. Adult perch are often piscivorous. Specimens were captured using $30 \times 6 \mathrm{~m}$ experimental gill nets anchored at the bottom and set overnight at various depths. Adult and juvenile whitefish, arctic char, perch and roach were caught on August 31, 2005 and in the first week of September 2005. One adult perch and Northern pike were obtained from a local professional fisherman on the west shore on February 20, 2006. Adult tench were sampled on the west shore on July 12, 2006 (Appendix 1). For each individual, approximately $5 \mathrm{~g}$ of white muscle tissue and the two sagittae, the largest of the three otolith pairs, were sampled. Data from otolith SIAs obtained on whitefish collected in 2004 (Dufour and Gerdeaux, 2007; Dufour et al., 2007) and Northern pike collected in 2008 (Gerdeaux and Dufour, 2012) were added to the present dataset.

\section{> MUSCLE PREPARATION AND ANALYSIS}

Muscle samples were kept frozen until they were prepared in the laboratory. They were freeze-dried overnight and reduced to a fine powder with a ball mill. Approximately $1 \mathrm{mg}$ was weighed with a high-precision microbalance and placed in tin cups for $\delta^{13} \mathrm{C}$ analysis.

Measurements were performed with a VG-Sira 10 or VG-Optima mass spectrometer coupled to a Carlo-Erba NA 1500 CHN element analyser at the Scottish Crop Research Institute (Scotland). Accuracy and precision were determined to be better than $\pm 0.15 \%$ (SD). The amount of carbon and nitrogen (weight:weight) in each sample was measured by the thermal conductivity detector of the $\mathrm{CHN}$ analyser; the analytical precision was $0.2 \%$.

Lipids can have a confounding influence on $\delta^{13} \mathrm{C}_{\text {muscle }}$ values. The $\mathrm{C}: \mathrm{N}$ atomic ratio calculated from elemental measurements obtained by $\mathrm{CHN}$ analysis was used to assess lipid content. Because lipids do not contain nitrogen there is a positive relationship between the $\mathrm{C}: \mathrm{N}$ atomic ratio and lipid content (Kline et al., 1998). The C:N values $(<4)$ of fish muscle tissues indicated a low lipid content in Lake Annecy (Janjua and Gerdeaux, 2011). For this reason, no treatment or C:N normalization of $\delta^{13} \mathrm{C}_{\text {muscle }}$ values were used to eliminate lipids or correct $\delta^{13} \mathrm{C}_{\text {muscle }}$ values.

\section{> OTOLITH PREPARATION AND ANALYSIS}

The sagittae were cleaned in $70 \%$ ethanol, and air dried. Because of their small size, whole otoliths of juveniles for all species as well as for adult tench were used. One otolith per individual was ground with a pestle and mortar into a fine powder. An aliquot $(100 \mu \mathrm{g})$ from this homogenised material was used for stable isotope analysis. For each adult fish (except for tench), one otolith was embedded into epoxy resin (Fluka-BioChemica ${ }^{\odot}$ ) following the procedure of Secor et al. (1991). The resin blocks were subsequently polished by hand until growth banding and the core were clearly visible on the sagittal plane. The blocks were then placed on glass slides. Slides were attached to a stage under the fixed high-precision dental drill of a computer-controlled Micromill microsampling apparatus (New Wave ${ }^{\odot}$; Dettman and Lohmann, 1995) that permitted a resolution of a few $\mu \mathrm{m}$. The innermost part of the core 
and visible growth marks on sagittal sections were digitized in real time as a series of threedimensional coordinates that were interpolated to create main sampling paths (Wurster et al., 1999). Arrays of intermediate sampling paths were calculated between main sampling paths. The resulting powder samples ('microsamples') drilled from each sampling path at a depth of 25 to $50 \mu \mathrm{m}$ were collected manually using a scalpel tip. The critical mass of aragonite for a single isotope analysis was $80-100 \mu \mathrm{g}$. When the amount of carbonate microsample obtained from one sampling path did not attain this critical mass, carbonate microsamples generated from two consecutive sampling paths were combined. The same sampling procedure was applied to the five species. However, the otolith shape and size differ among species. These morphological differences resulted in differences in the ease of sampling and in differences in microsample number per individual. Moreover, the relatively high mass of carbonate necessary for an analysis and the combination of consecutive sampling paths resulted in a relatively low spatial and temporal resolution. Thus it was estimated that the temporal resolution varies from 2 to 6 months depending on the species.

Stable isotope analyses were performed with a Continuous Flow Isotope Ratio Mass spectrometry (CF-IRMS) Finnigan MAT Delta plus XL equipped with GasBench II at the Stable Isotope Geochemistry Laboratory of the University of Lausanne (Switzerland). Carrara marble II (180-250 $\mu / 1.98 \mathrm{Hu})$ is used as internal standard for calibration every 10 samples with quantities ranging from $94 \mu \mathrm{g}$ to $221 \mathrm{mg}$. Analytical precision was $0.10 \%$ and $0.13 \%$ o for $\delta^{18} \mathrm{O}$ and $\delta^{13} \mathrm{C}$ values respectively (Spötl and Vennemann, 2003). $\delta^{18} \mathrm{O}$ and $\delta^{13} \mathrm{C}$ values were reported relative to the VPDB standard and plotted against the distance from the core to the ventral edge on the sagittal section (width in $\mu \mathrm{m}$ ) to generate intra-individual isotopic profiles.

\section{> THERMAL HISTORY RECONSTRUCTION}

Several studies have quantified the temperature dependence of otolith oxygen isotopes through the development of specific temperature-dependent fractionation equations based on fish growing in natural and laboratory environments (e.g., Hoie et al., 2004; Kalish, 1991; Patterson et al., 1993; Thorrold et al., 1997). Temperature reconstructions using these equations are relatively precise $\left(<1^{\circ} \mathrm{C}\right.$; Høie et al., 2004). Slopes are either statistically indistinguishable or similar to that reported by Kim et al. (2007) for inorganic aragonite but intercepts differ. Regarding freshwater fishes, three fractionation equations (Eq. (1)), (Patterson et al., 1993) (Eq. (2)), (Storm-Suke et al., 2007) (Eq. (3)), (Godiksen et al., 2010) are available:

$$
\begin{aligned}
& 1000 \operatorname{In} \alpha=18.56\left(1000 T^{-1}\right)-33.49 \text { developed for multiple genera in natural systems } \\
& 1000 \ln \alpha=20.69\left(1000 T^{-1}\right)-41.69 \text { developed for two Salvelinus species } \\
& 1000 \operatorname{In} \alpha=89.90\left(1000 T^{-1}\right)^{2}-617.19\left(1000 T^{-1}\right)+1089.24 \text { developed for Arctic char }
\end{aligned}
$$

where $\alpha$ is the fractionation factor between water and otolith aragonite, and $T$ is temperature in Kelvin. The relationship between $\alpha$ and $\delta^{18} \mathrm{O}_{\text {oto }}$ is as follows:

$$
\alpha=\left(\delta^{18} \mathrm{O}_{\text {oto }}+10^{3}\right) /\left(\delta^{18} \mathrm{O}_{\text {water }}+10^{3}\right) .
$$

An equation for marine fish, Micropogonias undulates, was developed by Thorrold et al. (1997):

$$
1000 \ln \alpha=18.56\left(1000 T^{-1}\right)-32.54 .
$$

\section{> ESTIMATION OF THE SOURCES OF CARBON IN OTOLITHS}

Carbon isotopes from otoliths are deposited under conditions of non-equilibrium with the ambient water because a substantial proportion of carbon is derived from metabolic sources ( $10-60 \%$ of total C deposited; Kalish, 1991; Schwarcz et al., 1998; Solomon et al., 2006). The two sources have very different isotopic values and $\delta^{13} \mathrm{C}_{\text {oto }}$ falls in between 
(Campana, 1999). The proportion $M$ of this metabolic carbon source incorporated into otolith aragonite can be expressed by a simple mass-balance equation between the two sources:

$$
\delta^{13} \mathrm{C}_{\text {oto }}=M \delta^{13} \mathrm{C}_{\text {met }}+(1-M) \delta^{13} \mathrm{C}_{\mathrm{DIC}}+\varepsilon_{\text {total }}
$$

where $\varepsilon_{\text {total }}$ is an enrichment factor between endolymphatic bicarbonates and aragonite and other fractionation steps.

A more detailed model including enrichment factors between food, blood, endolymph, and otolith is presented by Solomon et al. (2006). Assuming that fish $\delta^{13} \mathrm{C}_{\text {muscle }}$ represents an integrated estimate of $\delta^{13} \mathrm{C}_{\text {met }}$ and a $\varepsilon_{\text {total }}$ value equal to 0 (DeNiro and Epstein, 1978; Vander Zanden and Rasmussen, 2001), $M$ can also be expressed as:

$$
M=\left(\delta^{13} \mathrm{C}_{\text {oto }}-\delta^{13} \mathrm{C}_{\mathrm{DIC}}\right) /\left(\delta^{13} \mathrm{C}_{\text {muscle }}-\delta^{13} \mathrm{C}_{\mathrm{DIC}}\right) .
$$

\section{$>\delta^{18} \mathrm{O}_{\text {WATER }}$ AND $\delta^{13} \mathrm{C}_{\text {DIC }}$ IN LAKE ANNECY}

Variations in $\delta^{18} \mathrm{O}_{\text {water }}$ and $\delta^{13} \mathrm{C}_{\mathrm{DIC}}$ have been previously recorded in the various fish habitats of Lake Annecy (Dufour et al., 2007). It is difficult to select $\delta^{18} \mathrm{O}_{\text {water }}$ and $\delta^{13} \mathrm{C}_{\mathrm{DIC}}$ mean values that represent the average values over the life of a fish. Variability is higher in the littoral than in the pelagic zone, even more than in the hypolimnion (Dufour and Gerdeaux, 2007). Lake Annecy waters exhibit regular seasonal and vertical variations in $\delta^{18} \mathrm{O}_{\text {water }}$ (Danis et al., 2004; Gerdeaux and Dufour, 2012). Because of the stability in $\delta^{18} \mathrm{O}_{\text {water }}$ values among years and because the residence time of Lake Annecy water is more than four years (Danis et al., 2004), 2001 monthly averaged $\delta^{18} \mathrm{O}_{\text {water }}$ values calculated by Danis et al. (2004) for epilimnion and hypolimnion can be considered representative for all years considered in the present study. The epilimnion and hypolimnion monthly mean $\delta^{18} \mathrm{O}_{\text {water }}$ values varied from $-9.35 \%$ to $-8.60 \%$ 。 VSMOW and from $-9.35 \%$ o to $-9.10 \%$ VSMOW, respectively. The $\delta^{18} \mathrm{O}_{\text {water }}$ mean values chosen for this study depended on a priori knowledge of species habitat preferences obtained from the literature and on author knowledge of the fish community of Lake Annecy. According to previously described values, a range of variation in $\delta^{18} \mathrm{O}_{\text {water }}$ between $-8.95 \%$ 。 and $-9.35 \%$ was used for all fish except for Arctic char. The uncertainty of the results would be greater for roach and perch in particular, as these species live in the coastal and/or in the pelagic zone. For Arctic char, which always remain in deep waters, a range of $\delta^{18} \mathrm{O}_{\text {water }}$ between $-9.35 \%$ and $-9.10 \%$ o was used.

The maximum variation in $\delta^{13} \mathrm{C}_{\mathrm{DIC}}$ values encountered by fish (tench, roach, pike, perch) in the littoral zone was from $-6.5 \%$ in summer to $-9.0 \%$ in winter. The fish living around the thermocline (whitefish) encountered $\delta^{13} \mathrm{C}_{\mathrm{DIC}}$ values between $-8.0 \%$ at $15 \mathrm{~m}$ depth to $-6.8 \%$ at $10 \mathrm{~m}$ during the growing season. Fish living deeper in the hypolimnion (Arctic char) encountered almost no variation in the values, which ranged narrowly in the neighbourhood of $-9.5 \%$.

\section{> STATISTICAL ANALYSES}

Average isotopic values were compared with parametric tests (ANOVA, t-test). Nonparametric tests (Kruskal-Wallis (K.W.), Mann-Whitney (M.W.)) were used if the distributions were not normally distributed or if variances were unequal. All analyses were performed with SPLUS ${ }^{\odot}$ software.

\section{RESULTS}

\section{> INTRA-OTOLITH $\delta^{18} O$ AND $\delta^{13} \mathrm{C}$ PROFILES}

Low-resolution isotopic profiles were generated to reveal intra-otolith isotopic variations for five of the six studied species (Figure 1). At the species level, no general clear pattern was 

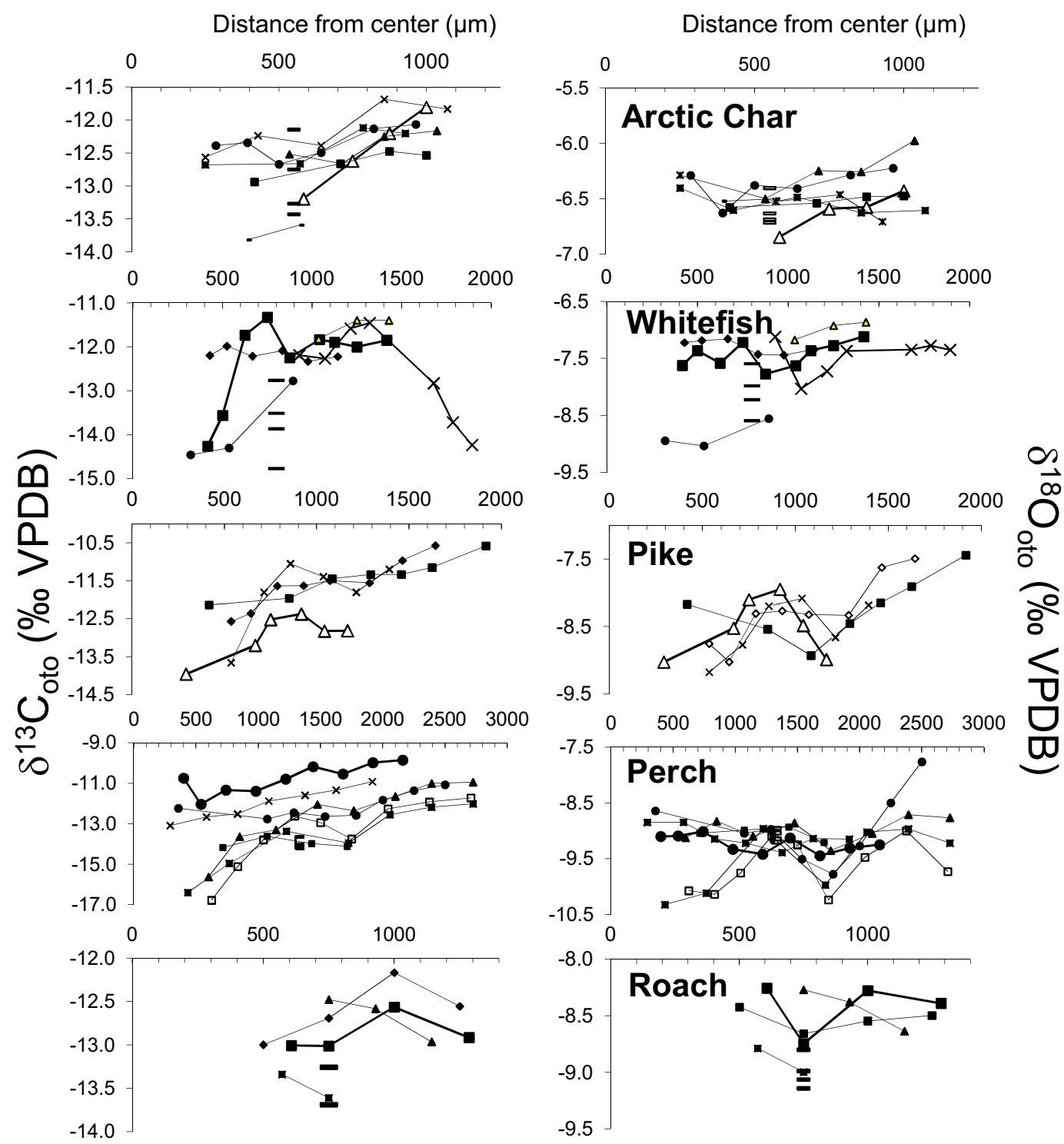

\section{Figure 1}

Intra-otolith variation in $\delta^{13} \mathrm{C}\left(\delta^{13} \mathrm{C}_{\text {oto }} \%\right.$, VPDB, left column) and $\delta^{18} \mathrm{O}\left(\delta^{18} \mathrm{O}_{\text {oto }} \%\right.$, VPDB, right column) for Arctic char (Salvelinus alpinus), whitefish (Coregonus lavaretus), pike (Esox lucius), perch (Perca fluviatilis) and roach (Rutilus rutilus) from Lake Annecy fish community. Each line represents one individual isotopic profile obtained by micromilling the otolith from the center (nucleus) to the edge.

observed for roach and whitefish, while pike, Arctic char and perch profiles usually exhibited similar patterns in seasonal and ontogenetic variations. However, perch profiles exhibited two patterns of $\delta^{18} \mathrm{O}_{\text {oto }}$ and $\delta^{13} \mathrm{C}_{\text {oto }}$ values at the beginning of life. There was a higher intraindividual variation in $\delta^{13} \mathrm{C}_{\text {oto }}$ values than in $\delta^{18} \mathrm{O}_{\text {oto }}$ values for the pike and perch species.

\section{> OTOLITH $\delta^{18}$ O AND THERMAL RECONSTRUCTION}

$\delta^{18} \mathrm{O}_{\text {oto }}$ values ranged for adults and juveniles from -9.4 to $-7.3 \%$ for pike, -9.3 to $-6.9 \%$ or whitefish, -9.1 to $-8.3 \%$ o for roach, -7.0 to $-6.0 \%$ o for Arctic char, -10.3 to $-7.8 \%$ o for perch and -8.9 to $8.7 \%$ o for tench (Figures 1 and 2). There were significant differences in adult $\delta^{18} \mathrm{O}_{\text {oto }}$ values among species (ANOVA, $F=102.67, p<0.001$ ). The lifetime mean $\delta^{18} \mathrm{O}_{\text {oto }}$ values for individual adults ranged from $-9.3 \%$ o \pm 0.5 for perch and $-6.2 \% \pm 0.2$ for Arctic char. The mean values did not differ between pike and whitefish $(|t|=0.90, d f=9, p>0.05)$ 


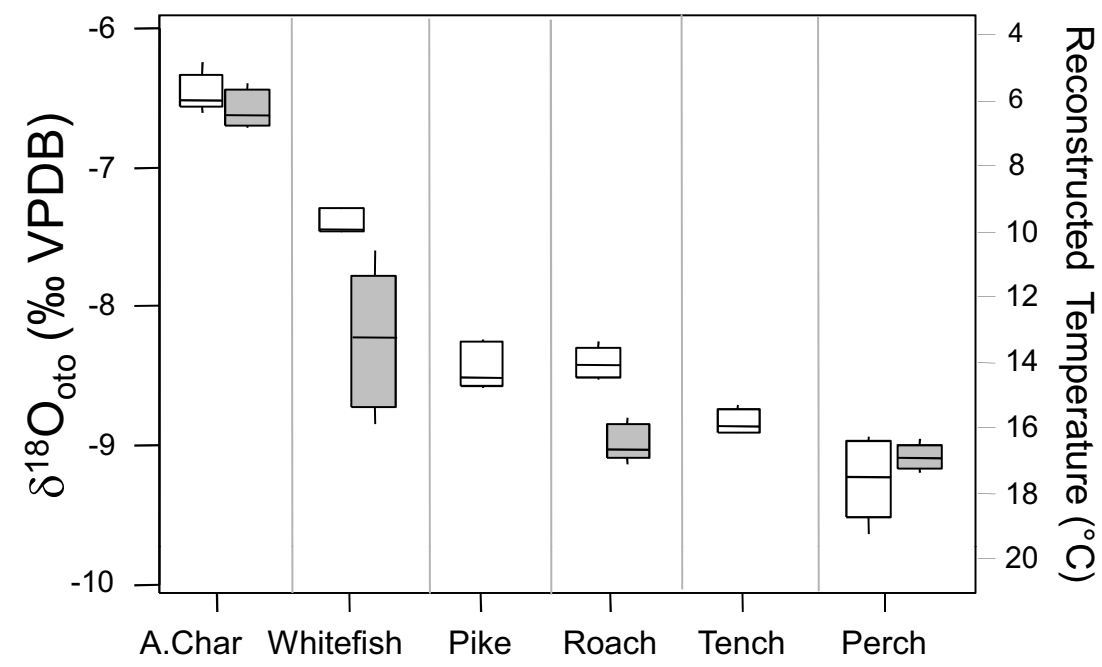

\section{Figure 2}

Total variation in otolith $\delta^{18} \mathrm{O}$ values $\left(\delta^{18} \mathrm{O}_{\text {oto }} \%\right.$, VPDB) of adults (white) and juveniles (shaded) of six fishes of Lake Annecy. Temperatures ( ${ }^{\circ} \mathrm{C}$ ) are calculated using the Patterson et al. (1993) fractionation equation and water $\delta^{18} \mathrm{O}$ values of $-9.35 \%$ measured for Lake Annecy.

and between pike and roach $(|t|=0.88, d f=7, p>0.05)$. Perch mean value was significantly lower to that of all other species $(p<0.05)$ (Figure 2).

Juvenile perch presented the lowest mean $\delta^{18} \mathrm{O}_{\text {oto }}$ values, Arctic char the highest mean $\delta^{18} \mathrm{O}_{\text {oto }}$ values (Figure 2). There was no significant difference in mean $\delta^{18} \mathrm{O}_{\text {oto }}$ values between adults and juveniles for Arctic char $(|t|=0.228, d f=10, p=0.824)$, perch $(|t|=0.835, d f=10$, $p=0.424)$ and roach $(t=1.733, d f=8, p=0.121)$ (Figures 1 and 2$)$. The $\delta^{18} \mathrm{O}_{\text {oto }}$ values differed significantly between juvenile and adult whitefish (M.W. $U=16, n=5, p=0.016$ ).

Temperature ranges reconstructed using Patterson's equation (Eq. (1)) and taking all adult microsample values and juveniles values were $9{ }^{\circ} \mathrm{C}$ to $18.6{ }^{\circ} \mathrm{C}$ for pike, $6.5^{\circ} \mathrm{C}$ to $17.5^{\circ} \mathrm{C}$ for whitefish, $10.4{ }^{\circ} \mathrm{C}$ to $24{ }^{\circ} \mathrm{C}$ for perch, $12.6{ }^{\circ} \mathrm{C}$ to $18.4{ }^{\circ} \mathrm{C}$ for roach, $2.8^{\circ} \mathrm{C}$ to $8.9^{\circ} \mathrm{C}$ for Arctic char (Figure 2). While temperatures were reconstructed using a range of $\delta^{18} \mathrm{O}_{\text {water }}$ values to take into account spatial and seasonal variability, Figure 2 presents results obtained with a single value $\left(\delta^{18} \mathrm{O}_{\text {water }}=-9.35 \%\right.$ o) for more clarity. A positive offset of $\sim 2{ }^{\circ} \mathrm{C}$ is obtained when temperatures are reconstructed with $\delta^{18} \mathrm{O}_{\text {water }}$ value of $-8.95 \%$.

\section{$>\delta^{13}$ C VALUES OF OTOLITH AND MUSCLE}

For adult specimens, $\delta^{13} \mathrm{C}_{\text {oto }}$ values ranged from -14.0 to $-10.6 \%$ for pike, -14.5 to $-11.3 \%$ o for whitefish, -15.0 to $-12.2 \%$ o for roach, -13.9 to $-11.5 \%$ o for Arctic char, -16.8 to $-9.9 \%$ o for perch and -14.6 to $-12.9 \%$ or tench (Figures 1 and 3). Mean $\delta^{13} \mathrm{C}_{\text {oto }}$ values for adult fish ranged from $-13.5 \%$ o for tench to $-12.0 \%$ o for pike (Figure 3 ). The measured value for tench is the only one which is statistically different from the other five species (ANOVA, $f=2.5$, $p=0.04$ ).

$\delta^{13} \mathrm{C}_{\text {muscle }}$ values for adult ranged from $-35.2 \%$ to $-27.2 \%$ for all species, with a maximum intra-species variation of $4.2 \%$ o for perch (Figure 3). There are signicant difference between species (ANOVA; $F=31.314, p<0.001$ ). Arctic char presented the lowest $\delta^{13} \mathrm{C}_{\text {muscle }}$ values, and tench presented the highest $\delta^{13} \mathrm{C}_{\text {muscle }}$ values; pike, roach and perch values are close to that of tench. The whitefish $\delta^{13} \mathrm{C}_{\text {muscle }}$ values were closer to those of Arctic char values than to those of any other species (Figure 3). Pike, roach, perch and tench $\delta^{13} \mathrm{C}_{\text {muscle }}$ values did not differ significantly ( $t$ test, $p>0.2$ ). Arctic char and whitefish values differed from each other and from that of the four other species ( $t$ test, $p<0.001)$. 

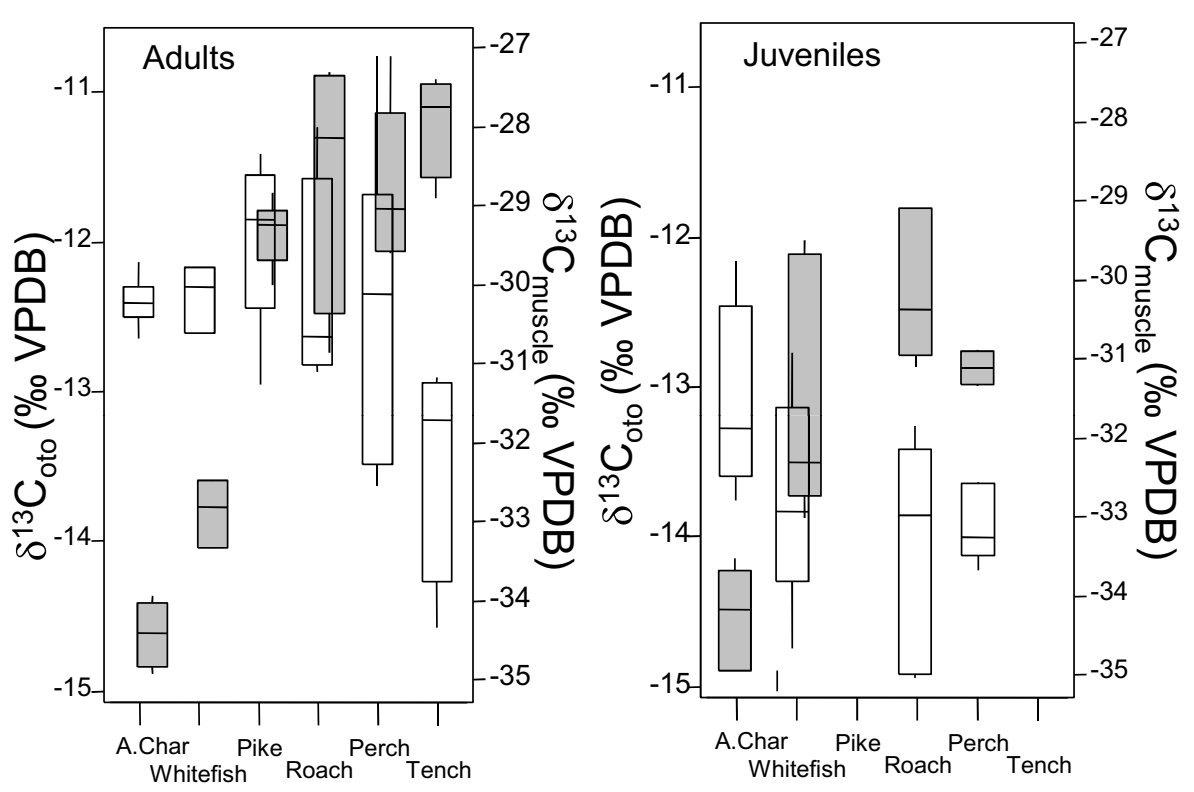

Figure 3

Total variation in otolith $\delta^{13} C$ values $\left(\delta^{13} C_{\text {oto }} \%\right.$, VPDB $)$ and muscle $\delta^{13} C\left(\delta^{13} C_{\text {muscle }} \%\right.$, VPDB of adults and juveniles of six fish species of Lake Annecy community. The $\delta^{13} C_{\text {muscle }}$ values are in shaded area.

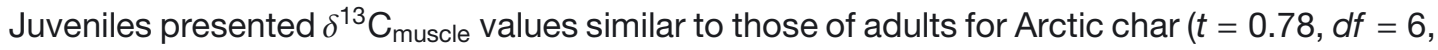
$p=0.47$ ), whitefish ( $t=1.91, d f=4, p=0.13$ ) and roach ( $t=-0.96, d f=5, p=0.38)$, and lower $\delta^{13} \mathrm{C}_{\text {muscle }}$ values than adults for juvenile perch $(t=-8.96, d f=1, p<0.001)$ (Figure 3 ).

\section{> METABOLIC CARBON IN OTOLITH AND THERMAL HABITAT}

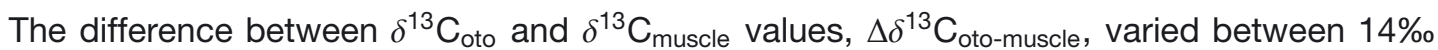
and 23\% among species (Figures 4 and 5). $\Delta \delta^{13} \mathrm{C}_{\text {oto-muscle }}$ was greatest for Arctic char living in the cold waters of the lake and was lowest for fish such as perch, tench and roach, which usually stay in the warm upper layers of the lake. There was a strong linear correlation between $\delta^{18} \mathrm{O}_{\text {oto }}$ and $\Delta \delta^{13} \mathrm{C}_{\text {oto-muscle }}$ for all individuals included in this study $\left(R^{2}=0.81, p<0.001\right)$ (Figure 4).

The estimated proportion of $M$ (metabolic carbon sources) incorporated into otolith aragonite, calculated from equation (7), varied between 0.1 and 0.35 among species (Figure 5). There was a significant, negative linear relationship between $M$ and $\delta^{18} \mathrm{O}_{\text {oto }}$, based on pooling of all the studied specimens $\left(r^{2}=0.5, p<0.001\right)$ (Figure 5).

\section{DISCUSSION}

\section{> RECONSTRUCTION OF FISH LIFE HISTORY PATTERNS FROM LOW-RESOLUTION MICROMILLING}

The present study was designed to provide insight into the thermal and metabolic history of Lake Annecy fishes at the level of the community, using otolith SIA. We used a micromilling technique (except for tench) from the core to the periphery to retrieve the intra-individual variation of adult fish at low resolution. Previous studies conducted on whitefish or pike have shown that it was possible to determine life history traits with a time step of the order 


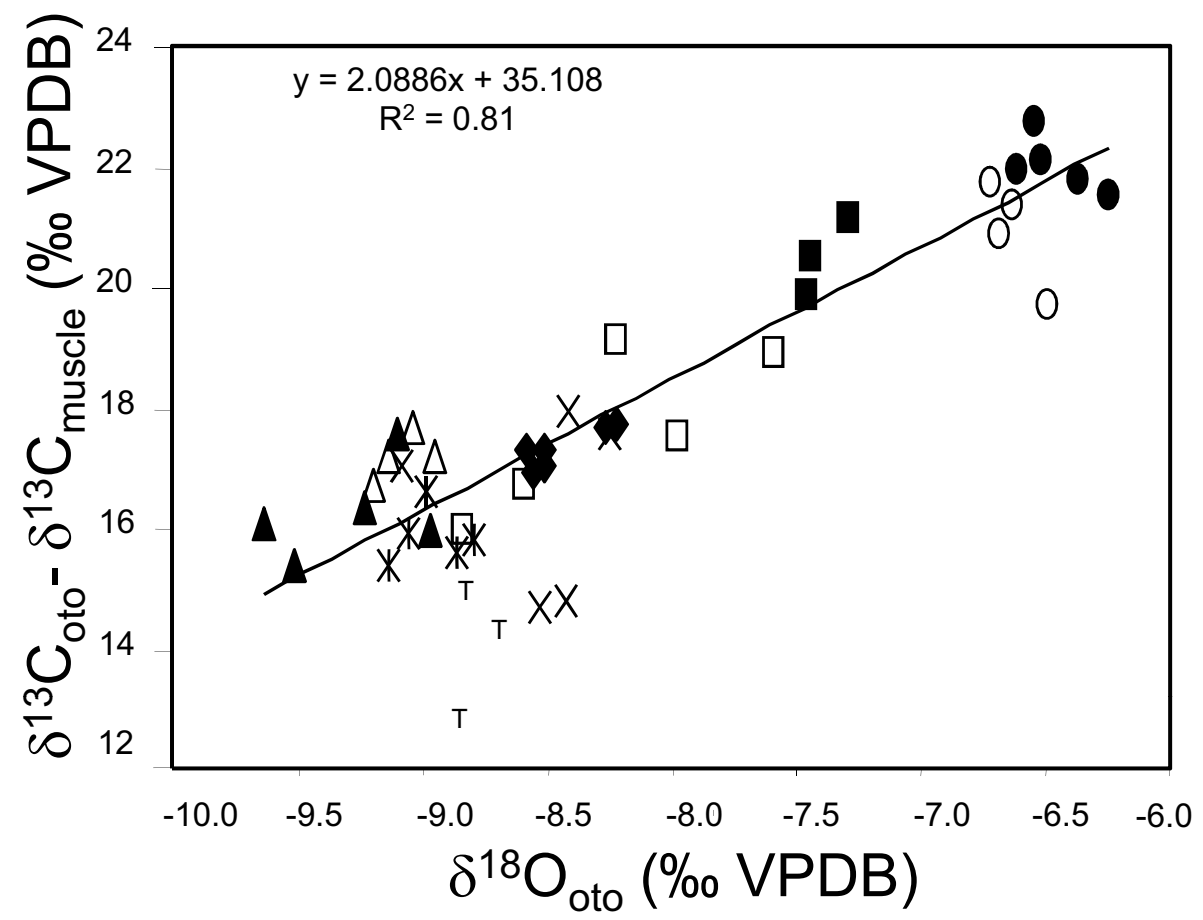

Figure 4

Relation between the difference in $\delta^{13} \mathrm{C}$ values between otolith and muscle $\left(\Delta \delta^{13} C_{\text {oto-muscle, \%o, VPDB) }}\right.$ and otolith $\delta^{18} \mathrm{O}\left(\delta^{18} \mathrm{O}_{\text {oto }} \%\right.$, VPDB) of adults for six fish species (pike $\bullet$, perch $\mathbf{\Delta}$, arctic char $\bullet$, whitefish $\square$, roach $x, T$ tench) and juveniles (perch $\Delta$, arctic char $\circ$, whitefish $\square$, roach *) of Lake Annecy community.

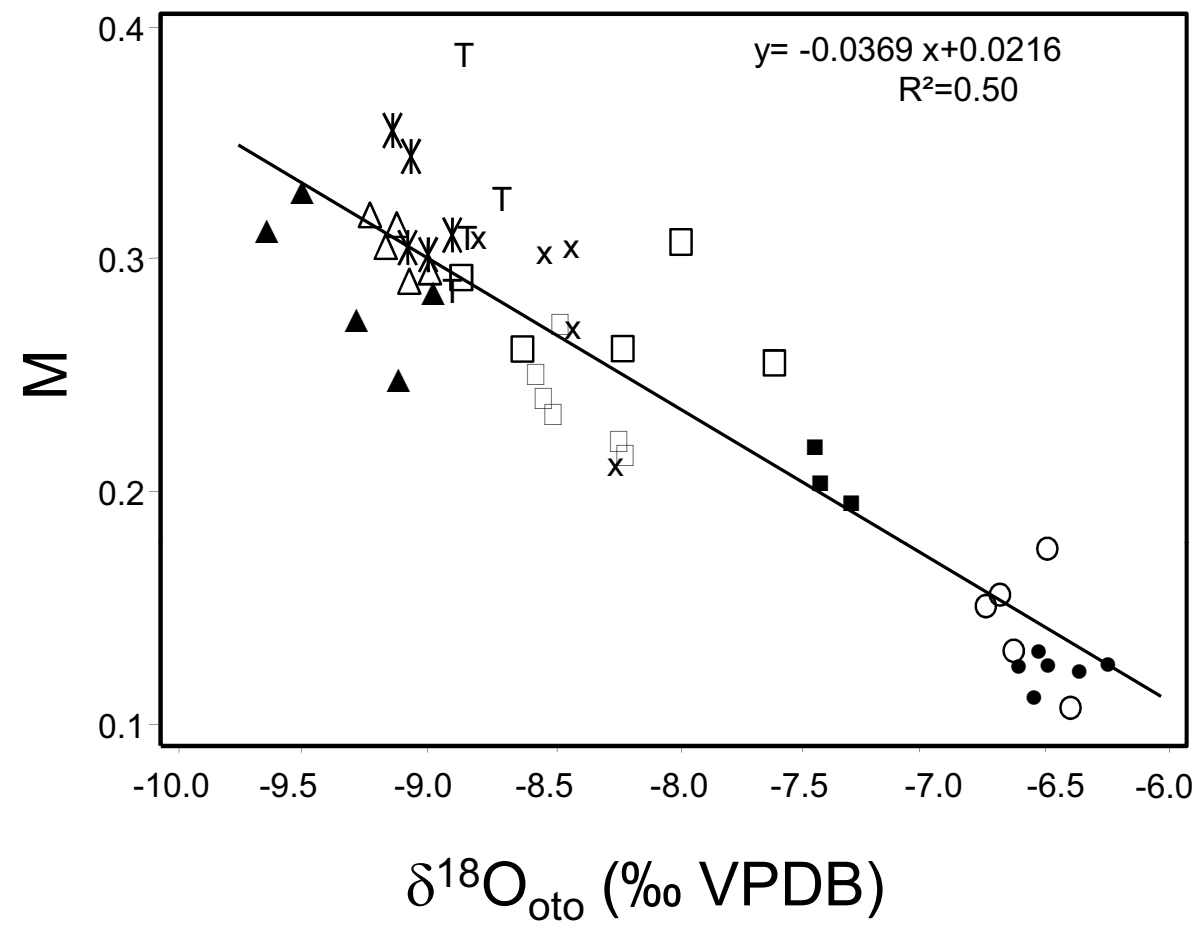

Figure 5

Relation between the contribution of metabolic carbon $(M)$ to otolith and otolith $\delta^{18} \mathrm{O}\left(\delta^{18} \mathrm{O}_{\text {oto }} \%\right.$, VPDB) values of six fish species (pike $\bullet$, perch $\mathbf{\Delta}$, arctic char $\bullet$, whitefish $\mathbf{\square}$, roach $x, T$ tench) of Lake Annecy community. 
of months with a high-resolution micromilling procedure associated with classical mass spectrometry (Dufour et al., 2007; Gerdeaux and Dufour, 2012). This approach is time-consuming and costly. Besides that, this study did not plan to describe individual fish histories. It aimed primarily to describe inter-specific variation in life history parameters recorded by otoliths and to test whether these findings were consistent with the current knowledge of the species' ecology. For this purpose, we determined $\delta^{18} \mathrm{O}_{\text {oto }}$ and $\delta^{13} \mathrm{C}_{\text {oto }}$ values for inter-specific comparisons by averaging the set of values over all the profiles (Figure 2). This procedure was preferred to the averaging obtained after grinding the entire otolith because, in this case, the part represented by the last year of life less overwhelmingly dominated the total otolith mass and, then, the mean otolith isotopic value. For tench, the whole otolith was ground, and we are aware that the average value does not have exactly the same meaning as it does for the other species.

The time average of the SIA profiles likely differs between species because of otolith shape and size. The studied species present markedly differing otolith shapes. The perch otolith is relatively flat, the growth marks are easily distinguishable by colour contrasts and their layout is relatively simple (only slightly wavy). In this case, the designed Micromill sampling paths easily match and recover synchronous aragonite deposits. With the chosen micromilling procedure, only pike and perch presented a range of intra-otolith $\delta^{18} \mathrm{O}_{\text {oto }}$ variation greater than $1 \%$ (Figure 1). This is not the case for roach otoliths, for which growth marks are more difficult to identify and present a complicated (very wavy) layout. Accordingly, extraction of nonsynchronous deposits might have led to a stronger averaging of the isotopic values. As a consequence, no clear intra-individual variations were noted, even at the inter-annual scale, for roach. Furthermore, the sub-seasonal scale of variation previously described for whitefish (Dufour and Gerdeaux, 2007; Dufour et al., 2007) could not be retrieved here, whereas good quality profiles were obtained for perch (Figure 1). Interestingly, the data showed clear inter-individual differences for perch, suggesting two different patterns in life history traits. For all perch profiles, lower $\delta^{13} \mathrm{C}_{\text {oto }}$ and $\delta^{18} \mathrm{O}_{\text {oto }}$ values were found at the beginning of life, but a $\delta^{18} \mathrm{O}_{\text {oto }}$ difference of $\sim 1 \%$ o at the beginning of life effectively discriminated two groups of individuals (Figure 1). Differences in $\delta^{13} \mathrm{C}_{\text {oto }}$ were also observed for certain individuals. This finding suggests that part of the population occupies the coastal environment, whereas the other part remains in the pelagic environment during the first year of life. The ecological plasticity of perch has been well described in Swedish lakes (Svanback and Eklov, 2006; Svanback et al., 2008) and is also demonstrated here for Lake Annecy for the first time.

\section{> CONSTRAINTS ON THERMAL HISTORY RECONSTRUCTION}

Variations in $\delta^{18} \mathrm{O}_{\text {oto }}$ values obtained after otolith micromilling or grinding were used to reconstruct the ranges of temperature experienced by the six Lake Annecy species selected for study (Figure 2). Such reconstruction, based on fractionation equations, required that the value of $\delta^{18} \mathrm{O}_{\text {water }}$ is known. Fractionation equations are highly sensitive to this parameter, the variability of which is often neglected. A $0.1 \%$ variation in the $\delta^{18} \mathrm{O}_{\text {water }}$ value (which corresponds to the analytical precision) results in a change of approximately $0.4{ }^{\circ} \mathrm{C}$ in the temperature calculated using equation (1). Despite the monitoring of $\delta^{18} \mathrm{O}_{\text {water }}$ (and of $\delta^{13} \mathrm{C}_{\mathrm{DIC}}$ ) for the different ecological zones, the choice of suitable $\delta^{18} \mathrm{O}_{\text {water }}$ (and $\delta^{13} \mathrm{C}_{\mathrm{DIC}}$ ) mean values that represent the average value over the life of a fish is difficult. The choice of the appropriate value must be based on a priori knowledge of species habitat preferences, obtained from the literature and from the authors' knowledge of the fish community of Lake Annecy. Moreover, the variability is higher in the epilimnion than in the hypolimnion and in the epilimnion of the littoral than of the pelagic zone (Dufour and Gerdeaux, 2007). This will result in an increased variability in $\delta^{18} \mathrm{O}_{\text {oto }}$ providing potentially a better way to discriminate fish habitat in the lake for roach and perch in particular because they live both in coastal and/or pelagic zones. However, the use of $\delta^{18} \mathrm{O}_{\text {water }}$ values will also increase the uncertainty of the calculated temperatures that will be greater for littoral/pelagic species than for benthic species. 
Another constraint on the results is the choice of the fractionation equation used for such temperature estimates. Several studies have suggested that oxygen isotope fractionation between otolith aragonite and ambient water was species-specific and recommended the use of species specific equations (Godiksen et al., 2010). Several authors have noticed significant differences among thermal estimates (Thorrold et al., 1997; Hoie et al., 2004; Storm-Suke et al., 2007). For Storm-Suke et al. (2007) and Rowell et al. (2005), this inconsistency precludes the broad use of any single fractionation equation for accurate thermal reconstruction of different species. It requires the use of a fractionation equation based on closely related species. Patterson's (1993) equation (Eq. (1)) was developed for a mixed assemblage of freshwater fish genera and has been used in previous studies on Lake Annecy. It was found to provide the best fit for both whitefish and pike (Gerdeaux and Dufour, 2012). Equation (1) was published prior to the equations that incorporated appropriate adjustments for the genus Salvelinus and for Arctic char (Godiksen et al., 2010; Storm-Suke et al., 2007). The availability of equations (2) and (3) provides an opportunity to test this assumption for the Lake Annecy Arctic char analysed in the present study. Arctic char usually live in the deep part of the lake hypolimnion, where the ambient temperature remains at approximately $5{ }^{\circ} \mathrm{C}$ (Klemetsen et al., 2003). Thirty-six of 37 temperature values calculated for Arctic char using equation (1) varied between $4{ }^{\circ} \mathrm{C}$ to $8.9^{\circ} \mathrm{C}$. Apart one very low value $\left(2.8^{\circ} \mathrm{C}\right)$, reconstructed temperatures are close to the minimum recorded in the deep hypolimnion of Lake Annecy. Indeed, the water temperature in Lake Annecy is never less than $4{ }^{\circ} \mathrm{C}$; moreover, below a depth of $30 \mathrm{~m}$, the water temperature is always less than $7{ }^{\circ} \mathrm{C}$. The temperature calculations using equations (2) and (3) yield values approximately 2 and $3.5^{\circ} \mathrm{C}$, respectively, below the minimum observed in Lake Annecy $\left(<4{ }^{\circ} \mathrm{C}\right)$. Geffen (2012) also found that equations (2) and (3) underestimated the temperatures for plaice (Pleuronectes platessa) captured at the same time in the North Sea. Conversely, temperatures calculated based on equation (5) (Thorrold et al., 1997) are $\sim 4{ }^{\circ} \mathrm{C}$ higher than values calculated with equation (1); these values are unrealistically high. Equations (1) (Patterson et al., 1993), developed for mixed assemblages of freshwater fishes, gives better calculations especially for Arctic char in Lake Annecy. These results suggest that interspecific differences or specific "vital effects" are not the only reason for apparent difference in fractionation. Additionally, and perhaps more importantly, the differences in temperature range and experimental design between the different calibration studies could explain the observed variations among studies in the fractionation factors. Otolith treatment method used in some studies (Storm-Suke et al. 2007; Godiksen et al., 2010) includes the roasting of samples at high temperature $\left(350{ }^{\circ} \mathrm{C}\right)$. It is well-know that aragonite is metastable and alters to calcite that has its own fractionation factor. It is possible that roasting has, at least partially, caused some recrystallization of aragonite into calcite. The use of the equations developed using this treatment may still be appropriate on any roasted otolith but might be inappropriate on untreated aragonite for which some correction (offset) should be applied. The large differences in temperatures derived between temperature equations developed specifically for Arctic char and the general equation of Patterson et al. (1993) observed in the present study might be due to this treatment difference. Therefore, we preferred to use a general equation, even if a specific equation was available for one of the species. Because the fractionation factor might vary in response to different causes, very precise temperature reconstruction, even for populations of the same species, might be difficult. Here, the goal is to estimate the thermal habitat, and the use of equation (1) appears suitable.

\section{$>$ WHAT $\delta^{18}$ O TELL ABOUT THE THERMAL DISTRIBUTION OF LAKE ANNECY FISH?}

The range of calculated temperatures at which the fish appeared to live, based on SIA, is highly consistent with the range of life traits known from the literature. Reconstructed temperature ranges were calculated from all microsample $\delta^{18} \mathrm{O}_{\text {oto }}$ values using equation (1) and two $\delta^{18} \mathrm{O}_{\text {water }}$ value ranges: from $-9.35 \%$ o to $-8.95 \%$ o for all pelagic and/or coastal species and from $-9.35 \%$ to $-9.10 \%$ o for Arctic char, which always remain in deep waters. Ranges 
were $9{ }^{\circ} \mathrm{C}$ to $18.6{ }^{\circ} \mathrm{C}$ for pike, $6.5^{\circ} \mathrm{C}$ to $17.5^{\circ} \mathrm{C}$ for whitefish, $10.4{ }^{\circ} \mathrm{C}$ to $24{ }^{\circ} \mathrm{C}$ for perch, $12.6^{\circ} \mathrm{C}$ to $18.4{ }^{\circ} \mathrm{C}$ for roach, and $4{ }^{\circ} \mathrm{C}$ to $8.9{ }^{\circ} \mathrm{C}$ (except one value at $2.8^{\circ} \mathrm{C}$ ) for Arctic char (Figure 2). The mean temperature for tench was $15.5^{\circ} \mathrm{C}$. Except for Arctic char, for which some calculated temperatures are lower than those observed in the lake in winter, the minimum calculated values were close to the values given in the literature at which the metabolism of somatic growth becomes active. For roach, this result is in accordance with the findings from feeding experiments in which the growth of roach is low or zero at temperatures below $12{ }^{\circ} \mathrm{C}$ (vanDijk et al., 2002). The growth of perch starts above $10^{\circ} \mathrm{C}$ (Karas, 1990). In a literature review Armstrong and Hawkins (2008) reported that the standard metabolic rate of pike is very low, below $8{ }^{\circ} \mathrm{C}$. Thus, the lowest reconstructed values using equation (1) correspond quite well with the thermal thresholds cited in the literature. It is above these thresholds that the metabolism of growth starts for pike, perch and roach.

Regarding the maximum well-being temperature for each species, data from the literature are quite variable. In this context, our calculations are consistent with the various upper limits of the ranges of temperature. The values for pike are generally close to $20^{\circ} \mathrm{C}$. In Canadian lakes, the estimated preferred temperature of adult pike is $\sim 23-24{ }^{\circ} \mathrm{C}$ (McCauley and Casselman, 1981). In Europe, optimum growth is considered to occur between 10 and $23^{\circ} \mathrm{C}$ (Keith and Allardi, 2001) or, more, approximately around $20^{\circ} \mathrm{C}$ (Bruslé and Quignard, 2001; Craig, 1996) and $25^{\circ} \mathrm{C}$ (Bevelhimer et al., 1985). In the literature, the data for roach are variable. Souchon and Tissot (2012) indicated that roach use a very wide temperature range, with a minimum ranging from 0 to $12{ }^{\circ} \mathrm{C}$ and a maximum ranging from 25 to $38{ }^{\circ} \mathrm{C}$. Broughton and Jones (1978) noted that the growth of juvenile roach begins at temperatures above $14{ }^{\circ} \mathrm{C}$. vanDijk et al. (2002) have shown experimentally that roach preferred temperatures above $25^{\circ} \mathrm{C}$ during the day. Tench has a mean reconstructed temperature at $15.5^{\circ} \mathrm{C}$, quite low considering that the species is often found in warm waters of the littoral zone. Tench fry show maximum growth to $24{ }^{\circ} \mathrm{C}$ (Backiel, 1986). Perch provide more consistent results, with literature data generally citing temperature ranges between $18^{\circ} \mathrm{C}$ and $27^{\circ} \mathrm{C}$ (Hokanson, 1977).

The lower reconstructed temperatures for roach than for perch raise questions. In Lake Annecy, the transparency of water (Secchi disk $\leqslant 10 \mathrm{~m}$ ) is, perhaps, the factor that changes the spatial segregation of fish and the temperatures at which they live. Due to competition for habitat and food in oligotrophic lakes with highly transparent water, roach might be displaced from the littoral zone by the presence of perch; the latter species is better able to forage in macrophyte patches (Svärdson, 1976; Winfield, 1986). The vertical positioning of the species could also be related more closely to avoiding predation by fish and birds than to finding a foraging optimum. In summer, very few fish stay in the littoral zone of the lake. The only fish observable are juvenile perch. Roach fry are never observed in the same areas. Currently, only a limited number of studies are available to support or contradict our observations based on $\delta^{18} \mathrm{O}_{\text {oto }}$ values. However, in situ studies of the vertical distribution of different species in lake with fishing nets or by echo sounding often show vertical spatial segregation, in which roach are positioned in higher water layers than those occupied by perch (Persson, 1986; Horppila et al., 2000). Kahl and Radke (2006) and Vasek et al. (2009) found that roach occurs during the day in the layer just above the thermocline $(3$ to $4.5 \mathrm{~m}$ ) and occupies the upper epilimnion $(0-3 \mathrm{~m})$ at night, whereas perch occupy the lower epilimnion and upper metalimnion (1.5-6 m). In Lake Annecy, the epilimnion is much thicker, approximately $15 \mathrm{~m}$, and the water transparency is always greater than $6 \mathrm{~m}$ (as measured by a Secchi disk). In Saidenbach Reservoir, which has a wide and deep pelagic zone, Kahl and Radke (2006) concluded that the spatial segregation of perch and roach is related to the temperature gradient. None of these studies provide any indication of the water transparency. Kahl and Radke's data were derived from a comparative analysis of various lakes of different sizes and depths, with simultaneous exclusion of confounding factors such as fish species composition, productivity, food or water transparency. Thus, more investigations regarding the perch-roach interaction in wide and deep lakes are necessary.

In this study, the use of otolith SIAs to study various fish species in Lake Annecy successfully located the positions of the thermal habitats of the species. The results for perch and roach 
highlight an interesting question of niche segregation previously mentioned by Svanback et al. (2008); this question has not yet been fully investigated.

\section{$>$ WHAT $\delta^{13} C_{\text {OTO VALUES TELL ABOUT FISH DIET AND METABOLISM? }}$}

SIA of carbon (associated with nitrogen) is routinely used in fish ecology and food-web studies through the documentation of fish diets and trophic positions. Although these studies are largely based on muscle SIA, SIA of otoliths has recently gained interest. According to previous authors of SIA studies, standard and active metabolism, diet, trophic position, DIC and depth are factors influencing $\delta^{13} \mathrm{C}_{\text {oto }}$ values at the intra or inter-specific levels (Schwarcz et al., 1998; Sherwood and Rose, 2003). It is well known that $\delta^{13} \mathrm{C}_{\text {oto }}$ values are not precipitated in equilibrium with $\delta^{13} \mathrm{C}_{\mathrm{DIC}}$ values (e.g. Weidman and Millner, 2000). Predicted $\delta^{13} \mathrm{C}_{\text {aragonite }}$ values using an enrichment factor averaging $2.7 \%$ o for inorganic aragonite (Romanek et al., 1992) and $\delta^{13} \mathrm{C}_{\mathrm{DIC}}$ values measured for Lake Annecy waters should range from $-6.3 \%$ o to $-3.8 \%$. All Lake Annecy fish have considerably lower $\delta^{13} \mathrm{C}_{\text {oto }}$ values than those predicted as previously described for whitefish (Dufour et al., 2007).

Simple two component mass-balance equations such as equation (7) are used in the literature to estimate the contribution of metabolic sources (e.g. Kalish, 1991). For Lake Annecy fish, the range of $M$ estimates is rather large ( $\sim 0.1$ for Arctic char to $\sim 0.35$ for roach; Figure 5$)$ but falls within the published estimates. Absolute $M$ estimates should be used with caution, and comparisons with previous estimates are difficult: (1) previous works have been conducted either on adults or juveniles while difference in ontogenetic growth rate might influence the contribution of the proportion of metabolic carbon; (2) the values of the fractionation factor $(\varepsilon)$ between diet and otoliths and between total blood bicarbonate and otoliths differ among studies. The effect of these factors on $M$ estimates is substantial (Solomon et al., 2006; Rowell, 2006; Dufour et al., 2007). Clearly, experimental studies in which carbon source components are labelled and the fractionation factor is independently determined are needed. Such investigations are beyond the scope of this study, in which we assumed the same fractionation factor for all studied species.

As a proportion of otolith carbon derives from metabolism, it has been considered that $\delta^{13} \mathrm{C}_{\text {oto }}$ could provide the ability to reconstruct diet information for marine (Jamieson et al., 2004; Weidman and Miller, 2000) and freshwater fish (Sako et al., 2007). In the current study, the potential relationship between $\delta^{13} \mathrm{C}_{\text {oto }}$ with diet was explored indirectly by comparison with $\delta^{13} \mathrm{C}_{\text {muscle }}$ values. Lake Annecy species show large variation (7\%) in mean specific $\delta^{13} \mathrm{C}_{\text {muscle }}$ values (Figure 3). In lakes, planktonic-pelagic consumers present lower $\delta^{13} \mathrm{C}$ values than benthic-littoral consumers as a result of different exposure levels to water turbulence of primary producers (periphyton and phytoplankton) at the bottom of the food web (France, 1995). The $\delta^{13} \mathrm{C}_{\text {muscle }}$ values measured in the present study well reflect the consumption of pelagic food for pelagic species (Arctic char) or littoral food for inshore species (roach, perch, tench) or a mix of both for whitefish (Figure 3). Contrasting with the large variations in $\delta^{13} \mathrm{C}_{\text {muscle }}$, Lake Annecy species displayed a limited ( 3\%) range of mean $\delta^{13} \mathrm{C}_{\text {oto }}$ values among species (Figure 3). The $\Delta \delta^{13} \mathrm{C}_{\text {oto-muscle }}$ is not a constant offset and varies between $14 \%$ and $23 \%$ o among species (Figure 4). Our data, therefore, do not support a direct influence of diet on inter-specific variation in $\delta^{13} \mathrm{C}_{\text {oto }}$. This lack of a simple relationship with diet, approximated by $\delta^{13} \mathrm{C}_{\text {oto-muscle }}$, is also observed at the individual level. Certain of the studied fishes present ontogenetic variations in $\delta^{13} \mathrm{C}_{\text {muscle }}$ values with adult individuals exhibiting lower (whitefish) or higher (perch) values than juvenile individuals (Figure 3). However, when it exists, the ontogenetic change in $\delta^{13} \mathrm{C}_{\text {oto }}$ values is always towards higher values and thus is in opposite direction to that of muscle for whitefish (Figure 3). Previous studies have explored the role of

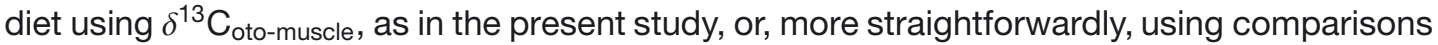
with dietary $\delta^{13} \mathrm{C}$. Such comparisons avoid the issue of varying trophic enrichment between diet and muscle (Elsdon et al., 2010) and the difference in turn-over between the two tissues. The lack of direct control by dietary $\delta^{13} \mathrm{C}$ values of inter-specific variations in $\delta^{13} \mathrm{C}_{\text {oto }}$ values was observed at the seasonal scale for Lake Annecy whitefish based on a comparison with 


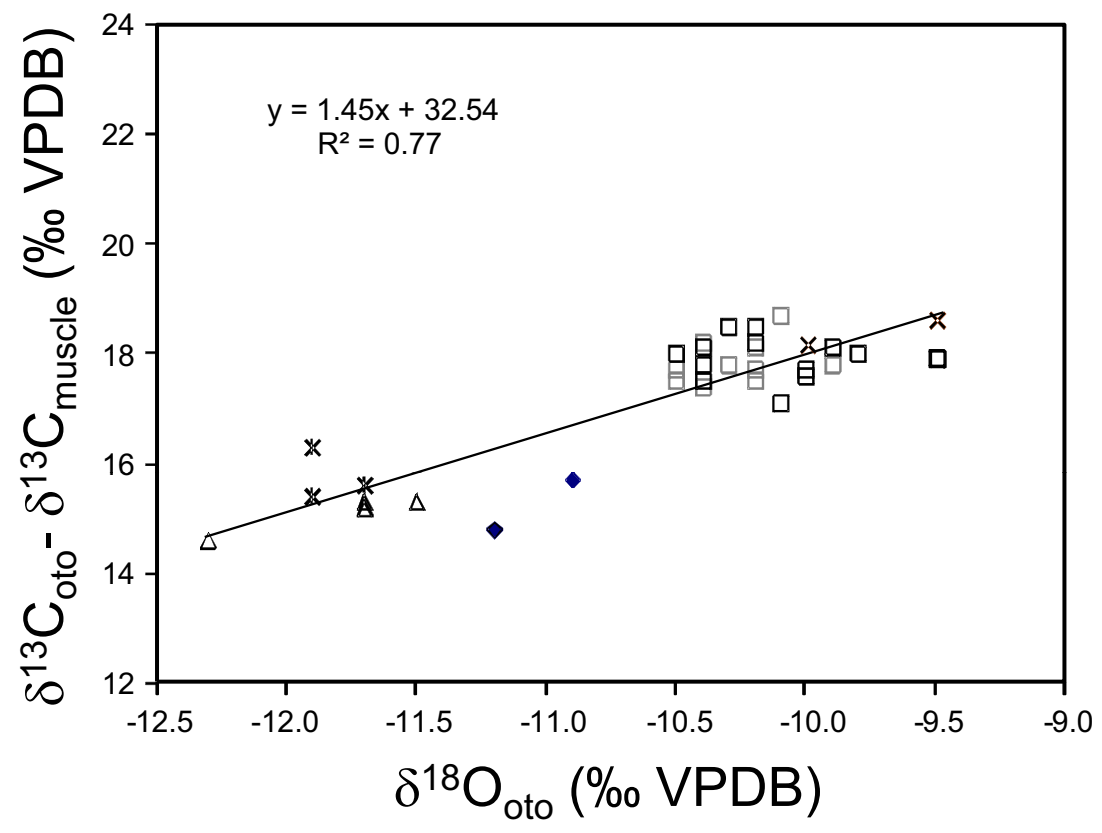

Figure 6

Relation between the $\delta^{13} C_{\text {oto }}-\delta^{13} C_{\text {muscle }}$ values and otolith $\delta^{18} O\left(\delta^{18} \mathrm{O}_{\text {oto }} \%\right.$, VPDB) values of six fish species (pike $\bullet$ perch $\Delta$, whitefish form "gangfelchen" $\square$, whitefish form "blaufelchen" $\square$, burbot $x$, pikeperch *) of Lake Constance community.

the $\delta^{13} \mathrm{C}$ values of zooplankton monitored over several years (Dufour et al., 2007). In contrast, in an experimental study of Fundulus heretoclitus fed on five isotopically distinct diets, Elsdon et al. (2010) found a strong correlation of bulk $\delta^{13} \mathrm{C}_{\text {oto }}$ with both diet and muscle $\delta^{13} \mathrm{C}$, and bulk $\delta^{13} \mathrm{C}_{\text {oto }}$ reflected the same total change in $\delta^{13} \mathrm{C}$ observed among the diet treatments. Even more intriguing are the results obtained by different studies of cod (Gadus morhua) that have produced contradictory conclusions. The direct influence of the dietary signal has been experimentally demonstrated by feeding two groups of individuals on isotopically different diets (Radtke et al., 1996). A comparison of the $\delta^{13} \mathrm{C}_{\text {muscle }}$ values of two cod stocks from the western and eastern Baltic Sea revealed that they feed on different organisms with different $\delta^{13} \mathrm{C}$ values but that this dietary difference was not reflected in differences between the $\delta^{13} \mathrm{C}_{\text {oto }}$ values (Deutsch and Berth, 2006). At the intra-individual level, the hypothesis of the control of cod ontogenetic $\delta^{13} \mathrm{C}_{\text {oto }}$ by dietary shift suggested for wild fish (Jamieson et al., 2004; Weidman and Miller, 2000), without constraints on ambient conditions and the composition of the diet, has not been supported by the analysis of reared fish fed on isotopically constant diets with ontogenetic and seasonal variation in $\delta^{13} \mathrm{C}_{\text {oto }}$ values (Høie et al., 2004).

The apparent discrepancy among the different results might be explained by variation in $M$ at the intra-specific (seasonal, ontogenetic, population) or inter-specific levels. $M$ is thought to be influenced by metabolic rate (Sherwood and Rose, 2003; Solomon et al., 2006) and because temperature influences the metabolic rate of poikilothermic fish (Clarke and Johnston, 1999), $M$ should increase with temperature. In the current study, a positive and significant linear relationship between $\Delta \delta^{13} \mathrm{C}_{\text {oto-muscle }}$ and $\delta^{18} \mathrm{O}_{\text {oto }}$ values (Figure 4) as well as a negative and significant linear relationship between $M$ and $\delta^{18} \mathrm{O}_{\text {oto }}$ (Figure 5) were observed when all the studied specimens of the various species of the Lake Annecy community were pooled for analysis. $\delta^{18} \mathrm{O}_{\text {oto }}$ values were used as thermal history descriptors in the current study, and the relationships found served to indicate a strong relationship between the temperatures expe-

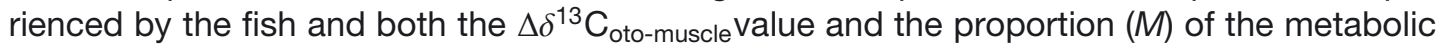

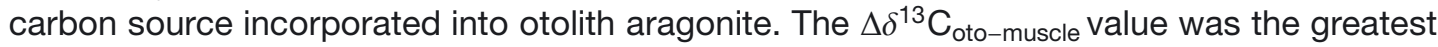
and the proportion of $M$ the lowest for Arctic char living in the cold waters of the lake. The $\Delta \delta^{13} \mathrm{C}_{\text {oto-muscle }}$ value was the lowest and $M$ the greatest for perch, tench and roach, which 
usually occur in warm layers near the surface of the lake. The increase in the proportion of metabolic source into otoliths as a function of temperature is described by an inter-species relationship.

The more energetic is the fish, the more otolith carbon might be derived from a metabolic source (Sherwood and Rose, 2003). The increasing variation in $M$ from Arctic char to perch and roach is consistent with the variation in respiratory rate among the different species available in the literature. Values of respiratory rate range from $40 \mathrm{mg} \mathrm{O}_{2} \mathrm{~kg}^{-1} \cdot \mathrm{h}^{-1}$ at $5{ }^{\circ} \mathrm{C}$ and $50 \mathrm{mg} \mathrm{O} \mathrm{kg}^{-1} \cdot \mathrm{h}^{-1}$ at $10^{\circ} \mathrm{C}$ for Arctic char (Holeton, 1973), approximately $75 \mathrm{mg} \mathrm{O} \mathrm{kg}^{-1} \cdot \mathrm{h}^{-1}$ at $10{ }^{\circ} \mathrm{C}$ for whitefish (Madenjian et al., 2006), $150 \mathrm{mg} \mathrm{O} \mathrm{Kg}^{-1} \cdot \mathrm{h}^{-1}$ at $20{ }^{\circ} \mathrm{C}$ for pike (Armstrong and Hawkins, 2008), $200 \mathrm{mg} \mathrm{O}_{2} \mathrm{~kg}^{-1} \cdot \mathrm{h}^{-1}$ for juvenile perch (Enders et al., 2006), and $120 \mathrm{mg} \mathrm{O}_{2} \mathrm{~kg}^{-1} \cdot \mathrm{h}^{-1}$ at $23^{\circ} \mathrm{C}$ for roach of $119 \mathrm{~g}$ (Hoelker, 2003). Thus, the fish-specific $\delta^{13} \mathrm{C}_{\text {oto }}$ values depended on the metabolic rate in relation to the living temperature of species, not on the species themselves. Archived muscle and otolith data for Lake Constance fish community (whitefish, pike, burbot, perch, pikeperch Sander lucioperca) (Dufour et al., 1998; Dufour, 1999) (Appendix 2) exhibit a linear relationship between $\Delta \delta^{13} \mathrm{C}_{\text {oto-muscle }}$ and $\delta^{18} \mathrm{O}_{\text {oto }}$ values (presented in appendix) similar to that of Lake Annecy that further supports our finding (Figure 6). Results of the present paper provide a rewarding starting point from which to conduct further studies on this generic relationship between the temperature of life of fish and the proportion of metabolic carbon incorporated in the otolith. To date, the existing data in the literature on both freshwater and marine fishes are too limited to allow these initial results to be compared.

\section{CONCLUSION}

The results of this study support the assertion that otolith SIA provides significant insights into the life history traits of fish in a lake community. Despite seasonal and spatial variations in $\delta^{18} \mathrm{O}_{\text {water }}$ (and $\delta^{13} \mathrm{C}_{\mathrm{DIC}}$ ) values, $\delta^{18} \mathrm{O}_{\text {oto }}$ values provide a consistent thermal history and vertical positioning of fish thermal habitats. The position of roach relative to perch raises the questions of competition between species, niche segregation and trade-offs in foraging efficiency that might result in divergent thermal habitats among populations. Moreover, perch $\delta^{18} \mathrm{O}_{\text {oto }}$ (and $\delta^{13} \mathrm{C}_{\text {oto }}$ ) values suggest two different habitat patterns, littoral versus more pelagic, during early life, highlighting the ecological plasticity of this species. These initial results encourage further studies of the thermal niche life history of this species, particularly in juveniles.

A linear relationship between the estimated metabolic carbon contribution to the otolith and the living temperature of fish, which includes all species of the studied community, was found. has also been found in Lake Constance. The hypothesis of a generic relationship provides a promising area of research. If this hypothesis is verified, it will allow the use of $\delta^{13} \mathrm{C}_{\text {oto }}$ as a proxy element of the average trophic position of different species in a lake community as a complement to new methods developed for studies of the organic matrix of fish otoliths (Gronkjaer et al., 2013; McMahon et al., 2011, 2013).

\section{ACKNOWLEDGEMENTS}

We would like to thank Catherine Pierre (LOCEAN, Paris) for Micromill access and Caroline Crépeau for her Master thesis work. We are indebted to Bernard Curt, professional fisherman on Lake Annecy and Christian Rühlé (Service de la Chasse et de la Pêche du Canton de Saint Gal, Lake Constance) who have been involved in this work by helping in the collection of samples.

We are also grateful to three reviewers for their helpful comments on an earlier version of the manuscript. 
Appendix 1. Sampling date, size, weight, $\delta^{13} \mathrm{C}$ values of otolith and muscle (\%, VPDB) and otolith $\delta^{18} \mathrm{O}$ (\%, VPDB) of the fish studied in Lake Annecy.

\begin{tabular}{|c|c|c|c|c|c|c|}
\hline Species & $\begin{array}{l}\text { Sampling } \\
\text { date }\end{array}$ & $\begin{array}{l}\text { Total length } \\
(\mathrm{mm})\end{array}$ & $\begin{array}{l}\text { Weight } \\
\text { (g) }\end{array}$ & $\begin{array}{l}\delta^{13} \mathrm{C} \\
\text { muscle }\end{array}$ & $\begin{array}{l}\delta^{13} \mathrm{C} \\
\text { otolith }\end{array}$ & $\begin{array}{l}\delta^{18} 0 \\
\text { otolith }\end{array}$ \\
\hline arctic char & $23 / 01 / 2006$ & 134 & 24.2 & -35.2 & -13.4 & -6.7 \\
\hline arctic char & $23 / 01 / 2006$ & 134 & 25.2 & -33.9 & -12.1 & -6.4 \\
\hline arctic char & $23 / 01 / 2006$ & 135 & 27.3 & -34.2 & -12.7 & -6.6 \\
\hline arctic char & $23 / 01 / 2006$ & 137 & 25.4 & -34.2 & -13.3 & -6.7 \\
\hline arctic char & $18 / 01 / 2006$ & 140 & 26.5 & -33.5 & -13.8 & -6.5 \\
\hline arctic char & $01 / 09 / 2005$ & 250 & 154 & -33.9 & -12.4 & -6.2 \\
\hline arctic char & $01 / 09 / 2005$ & 254 & 140 & -34.1 & -12.3 & -6.4 \\
\hline arctic char & $01 / 09 / 2005$ & 255 & 152 & -34.3 & -12.4 & -6.5 \\
\hline arctic char & $01 / 09 / 2005$ & 275 & 202 & -34.4 & -12.5 & -6.6 \\
\hline arctic char & $01 / 09 / 2005$ & 275 & 192 & -34.8 & -12.7 & -6.5 \\
\hline arctic char & $01 / 09 / 2005$ & 300 & 282 & -34.9 & -12.1 & -6.5 \\
\hline perch & $17 / 01 / 2006$ & 99 & 10.2 & -30.9 & -13.6 & -9.0 \\
\hline perch & $17 / 01 / 2006$ & 100 & 10.4 & -31.0 & -14.2 & -9.2 \\
\hline perch & $17 / 01 / 2006$ & 107 & 11.5 & -31.3 & -13.6 & -9.0 \\
\hline perch & $17 / 01 / 2006$ & 109 & 12.7 & -31.3 & -14.0 & -9.1 \\
\hline perch & $17 / 01 / 2006$ & 112 & 14.2 & -30.9 & -14.0 & -9.1 \\
\hline perch & $31 / 08 / 2005$ & 245 & 206 & -28.6 & -12.6 & -9.0 \\
\hline perch & $31 / 08 / 2005$ & 260 & 188 & -29.0 & -13.6 & -9.5 \\
\hline perch & $31 / 08 / 2005$ & 265 & 276 & -29.6 & -12.0 & -9.1 \\
\hline perch & $31 / 08 / 2005$ & 280 & 288 & -29.5 & -13.4 & -9.6 \\
\hline perch & $31 / 08 / 2005$ & 305 & 374 & -27.1 & -10.8 & -9.2 \\
\hline perch & $20 / 02 / 2006$ & 310 & 438 & -29.0 & -12.4 & -9.3 \\
\hline pike & $01 / 09 / 2005$ & 470 & 668 & -30.0 & -12.9 & -8.5 \\
\hline pike & $20 / 02 / 2006$ & 480 & 892 & -29.1 & -11.8 & -8.5 \\
\hline pike & $20 / 02 / 2006$ & 500 & 954 & -29.6 & -12.3 & -8.6 \\
\hline pike & $20 / 02 / 2006$ & 500 & 958 & -28.8 & -11.9 & -8.6 \\
\hline pike & $20 / 02 / 2006$ & 540 & 1214 & -29.2 & -11.4 & -8.2 \\
\hline pike & $20 / 02 / 2006$ & 550 & 1240 & -29.3 & -11.6 & -8.3 \\
\hline roach & $18 / 01 / 2006$ & 95 & 8.1 & -30.9 & -14.9 & -9.1 \\
\hline roach & $18 / 01 / 2006$ & 96 & 8.5 & -29.1 & -13.5 & -8.9 \\
\hline roach & $18 / 01 / 2006$ & 100 & 8.9 & -29.1 & -13.3 & -8.8 \\
\hline roach & $18 / 01 / 2006$ & 104 & 10.7 & -30.3 & -13.7 & -9.0 \\
\hline roach & $18 / 01 / 2006$ & 107 & 11.8 & -30.4 & -15.0 & -9.1 \\
\hline roach & $18 / 01 / 2006$ & 114 & 12.1 & -31.1 & -14.0 & -9.1 \\
\hline roach & $18 / 01 / 2006$ & 156 & 34.7 & -27.5 & -12.7 & -8.4 \\
\hline roach & $18 / 01 / 2006$ & 167 & 45.8 & -30.9 & -12.9 & -8.4 \\
\hline roach & $18 / 01 / 2006$ & 167 & 52.7 & -28.8 & -11.2 & -8.3 \\
\hline roach & $18 / 01 / 2006$ & 175 & 54 & -27.3 & -12.6 & -8.5 \\
\hline tench & $12 / 07 / 2006$ & 460 & 1637 & -27.8 & -13.3 & -8.7 \\
\hline tench & $12 / 07 / 2006$ & 475 & 1719 & -27.6 & -14.6 & -8.9 \\
\hline tench & $12 / 07 / 2006$ & 475 & 2023 & -28.0 & -13.0 & -8.8 \\
\hline tench & $12 / 07 / 2006$ & 485 & 2049 & -29.1 & -12.9 & -8.9 \\
\hline whitefish & $31 / 08 / 2005$ & 102 & 7.7 & -32.3 & -14.8 & -8.0 \\
\hline whitefish & $31 / 08 / 2005$ & 110 & 10.7 & -29.5 & -12.8 & -8.6 \\
\hline whitefish & $31 / 08 / 2005$ & 111 & 10.4 & -32.5 & -13.5 & -7.6 \\
\hline whitefish & $31 / 08 / 2005$ & 113 & 9.9 & -33.0 & -13.9 & -8.2 \\
\hline whitefish & $01 / 09 / 2005$ & 115 & 10.1 & -29.8 & -13.8 & -8.8 \\
\hline whitefish & $31 / 08 / 2005$ & 405 & 620 & -32.8 & -12.3 & -7.4 \\
\hline whitefish & $31 / 08 / 2005$ & 415 & 690 & -33.3 & -12.2 & -7.3 \\
\hline whitefish & $31 / 08 / 2005$ & 430 & 684 & -32.5 & -12.6 & -7.5 \\
\hline
\end{tabular}


Appendix 2. Size, weight, $\delta^{13} \mathrm{C}$ values of otolith and muscle (\%, VPDB) and otolith $\delta^{18} \mathrm{O}(\%$, VPDB) of 5 fish species of Lake Constance community (Dufour et al. 1998; Dufour, 1999). Samples were collected in 1995-1996. Muscle and otolith preparation and isotopic analysis were performed as described in Dufour et al. (1998) and Dufour et al. (2000).

\begin{tabular}{|l|c|c|c|c|c|}
\hline Species & $\begin{array}{c}\text { Total length } \\
(\mathrm{mm})\end{array}$ & $\begin{array}{c}\text { Weight } \\
(\mathrm{g})\end{array}$ & $\begin{array}{c}\delta^{13} \mathrm{C} \\
\text { muscle }\end{array}$ & $\begin{array}{c}\delta^{13} \mathrm{C} \\
\text { otolith }\end{array}$ & $\begin{array}{c}\delta^{18} \mathrm{O} \\
\text { otolith }\end{array}$ \\
\hline whitefish blaufelchen & 395 & 613 & -29.6 & -11.8 & -10.3 \\
\hline whitefish blaufelchen & 345 & 459 & -29.6 & -12.2 & -10.4 \\
\hline whitefish blaufelchen & ${ }^{* *}$ & ${ }^{* *}$ & -29.8 & -12.1 & -10.5 \\
\hline whitefish blaufelchen & 350 & 473 & -29.9 & -11.2 & -10.1 \\
\hline whitefish blaufelchen & 350 & 473 & -30.1 & -11.9 & -10.4 \\
\hline whitefish blaufelchen & 340 & 444 & -29.4 & -11.3 & -10.2 \\
\hline whitefish blaufelchen & 305 & 352 & -29.4 & -11.9 & -10.5 \\
\hline whitefish blaufelchen & 340 & 444 & -29.5 & -11.8 & -10.2 \\
\hline whitefish blaufelchen & 330 & 417 & -29.5 & -12.0 & -10.2 \\
\hline whitefish blaufelchen & 305 & 352 & -29.3 & -11.7 & -10.0 \\
\hline whitefish blaufelchen & 295 & 328 & -29.7 & -11.9 & -9.9 \\
\hline whitefish gangfelchen & 310 & 365 & -29.7 & -11.2 & -10.2 \\
\hline whitefish gangfelchen & 300 & 340 & -29.6 & -12.1 & -10.4 \\
\hline whitefish gangfelchen & 320 & 390 & -29.9 & -11.4 & -10.3 \\
\hline whitefish gangfelchen & 290 & 316 & -29.9 & -12.1 & -10.4 \\
\hline whitefish gangfelchen & 355 & 487 & -29.5 & -11.3 & -10.2 \\
\hline whitefish gangfelchen & 305 & 352 & -30.0 & -11.9 & -10.4 \\
\hline whitefish gangfelchen & 295 & 328 & -29.9 & -11.8 & -9.9 \\
\hline whitefish gangfelchen & 325 & 404 & -29.0 & -11.9 & -10.1 \\
\hline whitefish gangfelchen & 345 & 459 & -29.4 & -11.7 & -10.0 \\
\hline whitefish gangfelchen & 335 & 431 & -29.4 & -11.4 & -9.8 \\
\hline whitefish gangfelchen & 360 & 502 & -29.3 & -11.7 & -10.0 \\
\hline whitefish gangfelchen & 320 & 390 & -29.5 & -11.5 & -10.5 \\
\hline whitefish gangfelchen & 320 & 390 & -29.3 & -11.4 & -9.5 \\
\hline pike & 590 & 1300 & -25.9 & -11.1 & -11.2 \\
\hline pike & 670 & 1300 & -27.7 & -12.0 & -10.9 \\
\hline pikeperch & ${ }^{* *}$ & ${ }^{* *}$ & -27.5 & -11.2 & -11.9 \\
\hline pikeperch & 520 & 1194 & -27.3 & -11.9 & -11.9 \\
\hline pikeperch & 325 & 238 & -30.9 & -11.3 & -11.7 \\
\hline burbot & 340 & 250 & -31.6 & -13.5 & -9.5 \\
\hline burbot & 200 & 48 & -29.2 & -13.9 & -11.0 \\
\hline perch & 160 & 64 & -28.7 & -13.4 & -11.7 \\
\hline perch & & & & & \\
\hline perch & & & -28.5 & -13.9 & -12.3 \\
\hline perch & & & & & \\
\hline
\end{tabular}

\section{REFERENCES}

Armstrong J.D. and Hawkins L.A., 2008. Standard metabolic rate of pike, Esox lucius: variation among studies and implications for energy flow modelling. Hydrobiologia, 601, 83-90.

Aubert M., Williams I.S., Boljkovac K., Moffat I., Moncel M.H., Dufour E. and Grun R., 2012. In situ oxygen isotope micro-analysis of faunal material and human teeth using a SHRIMP II: a new tool for palaeo-ecology and archaeology. J. Archaeol. Sci., 39, 3184-3194.

Backiel T., 1986. Masking effect of variability of growth on its estimation in juvenile tench, Tinca tinca (L.), reared at different temperatures. Pol. Arch. Hydrobiol., 33, 69-95.

Bergman E. and Greenberg L.A., 1994. Competition between a planktivore, a benthivore and a species with ontogenetic diet shifts. Ecology, 75, 1233-1245.

Bevelhimer M.S., Stein R.A. and Carline R.F., 1985. Assessing significance of physiological differences among 3 esocids with a bioenergetics model. Can. J. Fish. Aquat. Sci., 42, 57-69.

Broughton N.M. and Jones N.V., 1978. An investigation into the growth of O-group roach, (Rutilus rutilus L.) with special reference to temperature. J. Fish Biol., 12, 345-357.

Bruslé J. and Quignard J.P., 2001. Biologie des poissons d'eau douce européens. Lavoisier, Paris. 
Campana S.E., 1999. Chemistry and composition of fish otoliths: pathways, mechanisms and applications. Mar. Ecol. Prog. Ser., 188, 263-297.

Carpenter S.J., Erickson J.M. and Holland F.D., 2003. Migration of a Late Cretaceous fish. Nature, 423, 70-74.

Casselman J.M., 1978. Effects of environmental factors on growth, survival, activity, and exploitation of northern pike. Am. Fish. Soc. Special Publication, 114-128.

Clarke A. and Johnston N.M., 1999. Scaling of metabolic rate with body mass and temperature in teleost fish. J. Anim. Ecol. 68, 893-905.

Craig J., 1996. Pike: biology and exploitation. Chapman \& Hall, $320 \mathrm{p}$.

Danis P.A., von Grafenstein U., Masson-Delmotte V., Planton S., Gerdeaux D. and Moisselin J.M., 2004. Vulnerability of two European lakes in response to future climatic changes. Geophys. Res. Lett., 31.

Degens E.T., Deuser W.G. and Haedrich R.L., 1969. Molecular structure and composition of fish otoliths. Mar. Biol., 2, 105-113.

DeNiro M.J. and Epstein S., 1978. Influence of diet on the distribution of carbon isotopes in animals. Geochim. Cosmochim. Acta, 42, 495-506.

Dettman D.L. and Lohmann K.C., 1995. Microsampling carbonates for stable isotope and minor element analysis: Physical separation of samples on a 20 micrometer scale. J. Sediment. Res., 65, 566-569.

Deutsch B. and Berth U., 2006. Differentiation of western and eastern Baltic Sea cod stocks (Gadus morhua) by means of stable isotope ratios in muscles and otoliths. J. Appl. Ichthyol., 22, 538-539.

Dufour E., 1999. Implications paléoenvironnementales et paléoalimentaires des abondances isotopiques en carbone et azote des poissons téléostéens. Thèse de doctorat de l'Université Pierre et Marie Curie, $198 \mathrm{p}$.

Dufour E. and Gerdeaux D., 2001. Contribution of stable isotopes to fish ecological studies. Cybium, 25, 369-382.

Dufour E. and Gerdeaux D., 2007. Summer depth positioning of whitefish (Coregonus lavaretus) in Lake Annecy inferred from oxygen thermometry of otoliths. In: Jankun M., Brzuzan P., Hliwa P. and Luczynski M. (eds.), Biology and Management of Coregonid Fishes - 2005, 195-204.

Dufour E., Bocherens H., Gerdeaux D., Ruhlé C. and Mariotti A., 1998. Stable carbon and isotope approach to the distinction between Blaufelchen and Gangfish (Coregonus lavaretus) in lake Constance. Arch. hydrobiol. Spec. Isuues. Advanc. Limnol., 50, 121-129.

Dufour E., Cappetta H., Denis A., Dauphin Y. and Mariotti A., 2000. La diagenèse des otolithes par la comparaison des données microstructurales, minéralogiques et géochimiques : application aux fossiles du Pliocène du Sud-Est de la France. Bull. Soc. Géol. France, 171, 521-532.

Dufour E., Gerdeaux D. and Wurster C.M., 2007. Whitefish (Coregonus lavaretus) respiration rate governs intra-otolith variation of $\delta^{13} \mathrm{C}$ values in Lake Annecy. Can. J. Fish. Aquat. Sci., 64, 1736-1746.

Elsdon T.S., Ayvazian S., McMahon K.W. and Thorrold S.R., 2010. Experimental evaluation of stable isotope fractionation in fish muscle and otoliths. Mar. Ecol. Prog. Ser., 408, 195-205.

Enders E.C., Boisclair D., Boily P. and Magnan P., 2006. Effect of body mass and water temperature on the standard metabolic rate of juvenile yellow perch, Perca flavescens (Mitchill). Environ. Biol. Fishes, 76, 399-407.

France R.L., 1995. Carbon-13 enrichment in benthic compared to planktonic algae: foodweb implications. Mar. Ecol. Prog. Ser., 124, 307-312.

Geffen A.J., 2012. Otolith oxygen and carbon stable isotopes in wild and laboratory-reared plaice (Pleuronectes platessa). Environ. Biol. Fishes, 95, 419-430.

Gerdeaux D. and Dufour E., 2012. Inferring occurrence of growth checks in pike (Esox lucius) scales by using sequential isotopic analysis of otoliths. Rapid Commun. Mass Spectrom., 26, 785-792.

Gerdeaux D. and Perga M.E., 2006. Changes in whitefish scales delta C-13 during eutrophication and reoligotrophication of subalpine lakes. Limnol. Oceanogr., 51, 772-780.

Gerdeaux D., Bergeret S., Fortin J. and Baronnet T., 2001. Diet and seasonal patterns of food intake by Coregonus lavaretus in Lake Annecy, comparison with the diet of the other species of the fish community. Arch. Hydrobiol. Spec. Issues Adv. Limnol., 57, 199-207. 
Godiksen J., Svenning M.A., Dempson J.B., Marttila M., Storm-Suke A. and Power M., 2010. Development of a species-specific fractionation equation for Arctic charr (Salvelinus alpinus (L.)): an experimental approach. Hydrobiologia, 650, 67-77.

Gronkjaer P., Pedersen J.B., Ankjaero T.T., Kjeldsen H., Heinemeier J., Steingrund P., Nielsen J.M. and Christensen J.T., 2013. Stable N and C isotopes in the organic matrix of fish otoliths: validation of a new approach for studying spatial and temporal changes in the trophic structure of aquatic ecosystems. Can. J. Fish. Aquat. Sci., 70, 143-146.

Hanson N.N., Wurster C.M. and Todd C.D., 2010. Comparison of secondary ion mass spectrometry and micromilling/continuous flow isotope ratio mass spectrometry techniques used to acquire intraotolith delta O-18 values of wild Atlantic salmon (Salmo salar). Rapid Commun. Mass Spectrom., 24, 2491-2498.

Hoeinghaus D.J. and Zeug S.C., 2008. Can stable isotope ratios provide for community-wide measures of trophic structure? Comment. Ecology, 89, 2353-2357.

Hoelker F., 2003. The metabolic rate of roach in relation to body size and temperature. J. Fish Biol., 62, 565-579.

Hoie H., Andersson C., Folkvord A. and Karlsen O., 2004. Precision and accuracy of stable isotope signals in otoliths of pen-reared cod (Gadus morhua) when sampled with a high-resolution micromill. Marine Biology, 144, 1039-1049.

Hokanson K.E.F., 1977. Temperature requirements of some percids and adaptations to seasonal temperature cycle. J. Fish Res. Board Can., 34, 1524-1550.

Holeton G.F., 1973. Respiration of Arctic Char (Salvelinus alpinus) From a High Arctic Lake. J. Fish Res. Board Can., 30, 717-723.

Horppila J., Ruuhijarvi J., Rask M., Karppinen C., Nyberg K. and Olin M., 2000. Seasonal changes in the diets and relative abundances of perch and roach in the littoral and pelagic zones of a large lake. J. Fish Biol., 56, 51-72.

Huxham M., Kimani E., Newton J. and Augley J., 2007. Stable isotope records from otoliths as tracers of fish migration in a mangrove system. J. Fish Biol., 70, 1554-1567.

Jamieson R.E., Schwarcz H.P. and Brattey J., 2004. Carbon isotopic records from the otoliths of Atlantic cod (Gadus morhua) from eastern Newfoundland, Canada. Fish Res., 68, 83-97.

Janjua M.Y. and Gerdeaux D., 2011. Evaluation of food web and fish dietary niches in oligotrophic Lake Annecy by gut content and stable isotope analysis. Lakes Reserv. Manage., 27, 115-127.

Jardine T.D., Kidd K.A. and O'Driscoll N., 2013. Food web analysis reveals effects of pH on mercury bioaccumulation at multiple trophic levels in streams. Aquat. Toxicol., 132, 46-52.

Kahilainen K.K., Patterson W.P., Sonninen E., Harrod C. and Kiljunen M., 2014. Adaptive radiation along a thermal gradient: preliminary results of habitat use and respiration rate divergence among Whitefish morphs. Plos One, 9(11).

Kahl U. and Radke R.J., 2006. Habitat and food resource use of perch and roach in a deep mesotrophic reservoir: enough space to avoid competition? Ecol. Freshw. Fish, 15, 48-56.

Kalish J.M., 1991. C-13 and O-18 isotopic disequilibria in fish otoliths - metabolic and kinetic effects. Mar. Ecol. Prog. Ser., 75, 191-203.

Karas P., 1990. Seasonal changes in growth and standard metabolic-rate of juvenile perch, Perca fluviatilis L. J. Fish Biol., 37, 913-920.

Keith P. and Allardi J., 2001. Atlas des poissons d'eau douce de France, Paris, 387 p.

Kim S.T., O'Neil J.R., Hillaire-Marcel C. and Mucci A., 2007. Oxygen isotope fractionation between synthetic aragonite and water: Influence of temperature and Mg2+ concentration. Geochim. Cosmochim. Acta, 71, 4704-4715.

Klemetsen A., Amundsen P.A., Dempson J.B., Jonsson B., Jonsson N., O'Connell M.F. and Mortensen E., 2003. Atlantic salmon Salmo salar L., brown trout Salmo trutta L. and artic charr salvelinus alpinus (L.): a review of aspects of their life histories. Ecol. Freshw. Fish, 12, 1-59.

Kline T.C., Wilson W.J. and Goering J.J., 1998. Natural isotope indicators of fish migration at Prudhoe Bay, Alaska. Can. J. Fish. Aquat. Sci., 55, 1494-1502.

Madenjian C.P., O'Connor D.V., Pothoven S.A., Schneeberger P.J., Rediske R.R., O’Keefe J.P., Bergstedt R.A., Argyle R.L. and Brandt S.B., 2006. Evaluation of a lake whitefish bioenergetics model. T. Am. Fish Soc., 135, 61-75. 
McCauley R.W. and Casselman J.M., 1981. The final preferendum as an index of the temperature for optimum growth in fish. In: Tiews K. (ed.), World Symposium on Aquaculture in Heated Effluents and Recirculation Systems. Heenemann Verlagsgesellschaf, pp. 81-93.

McMahon K.W., Berumen M.L., Mateo I., Elsdon T.S. and Thorrold S.R., 2011. Carbon isotopes in otolith amino acids identify residency of juvenile snapper (Family: Lutjanidae) in coastal nurseries. Coral Reefs, 30, 1135-1145.

McMahon K.W., Hamady L.L. and Thorrold S.R., 2013. A review of ecogeochemistry approaches to estimating movements of marine animals. Limnol. Oceanogr., 58, 697-714.

Michener R. and Lajtha K., 2007. Stable isotopes in ecology and environmental science. 2nd edition. ISBN 978-1-4051-2680-9. Ecological Methods and Concepts Series. Blackwell Publishing, Malden, Massachusetts 02148-5020, 566 p.

Patterson W.P., Smith G.R. and Lohmann K.C., 1993. Continental paleothermometry and seasonality using the isotopic composition of aragonitic otoliths of freshwater fishes. In Continental Climate Change from Isotopic Records. In: Swart P.K., Lohmann K.C., McKenzie J., and Savin S. (ed.), Continental Climate Change from Isotopic Records., Washington, DC, 191-202.

Perga M.E. and Gerdeaux D., 2005. Are fish what they eat all year round? Oecologia, 144, 598-606.

Persson L., 1986. Temperature-induced shift in foraging ability in 2 fish species, roach (Rutilus rutilus) and perch (Perca fluviatilis) - implications for coexistence between poïkilotherms. J. Anim. Ecol., 55, 829-839.

Romanek C.S., Grossman E.L. and Morse J.W., 1992. Carbon isotopic fractionation in synthetic aragonite and calcite - Effects of temperature and precipitation rate. Geochim. Cosmochim. Ac., 56, 419-430.

Rowell K., Flessa K.W., Dettman D.L. and Roman M., 2005. The importance of Colorado River flow to nursery habitats of the Gulf corvina (Cynoscion othonopterus). Can. J. Fish. Aquat. Sci., 62, 2874-2885.

Sako A., MacLeod K.G. and O'Reilly C.M., 2007. Stable Oxygen and Carbon Isotopic Compositions of Lates stappersii Otoliths from Lake Tanganyika, East Africa J. Great Lakes Res. 33, 806-815.

Schwarcz H.P., Gao Y., Campana S., Browne D., Knyf M. and Brand U., 1998a. Stable carbon isotope variations in otoliths of Atlantic cod (Gadus morhua). Can. J. Fish. Aquat. Sci., 55, 1798-1806.

Schwarcz H.P., Simpson J.J. and Stringer C.B., 1998b. Neanderthal skeleton from Tabun: U-series data by gamma-ray spectrometry. J. Hum. Evol., 35, 635-645.

Secor D.H., Dean J.M. and Laban E.H., 1991. Otolith removal and preparation for microstructural examination: A user manual. Baruch. Inst.

Sherwood G.D. and Rose G.A., 2003. Influence of swimming form on otolith delta C-13 in marine fish. Mar. Ecol. Prog. Ser., 258, 283-289.

Solomon C.T., Weber P.K., Cech J.J., Ingram B.L., Conrad M.E., Macharam M.V., Pogodina A.R. and Franklin R.L., 2006. Experimental determination of the sources of otolith carbon and associated isotopic fractionation. Can. J. Fish. Aquat. Sci., 63, 79-89.

Souchon Y. and Tissot L., 2012. Synthesis of thermal tolerances of the common freshwater fish species in large Western Europe rivers. Knowl. Manag. Aquat. Ecosyst., 405, 03.

Spötl C. and Vennemann T.W., 2003. Continuous-flow isotope ratio mass spectrometric analysis of carbonate minerals. Rapid Communications in Mass Spectrometry, 17, 1004-1006.

Storm-Suke A., Dempson J.B., Reist J.D. and Power M., 2007. A field-derived oxygen isotope fractionation equation for Salvelinus species. Rapid Communications in Mass Spectrometry, 21, 41094116.

Svanback R. and Eklov P., 2006. Genetic variation and phenotypic plasticity: causes of morphological and dietary variation in Eurasian perch. Evolutionary Ecology Research, 8, 37-49.

Svanback R., Eklov P., Fransson R. and Holmgren K., 2008. Intraspecific competition drives multiple species resource polymorphism in fish communities. Oikos, 117, 114-124.

Svärdson G., 1976. Interspecific population dominance in fish communities of Scandinavian lakes. Institut of Freshwater Research Drottningholm, Sweden, 55, 144-171.

Thorrold S.R., Campana S.E., Jones C.N. and Swart P.K., 1997. Factors determining $\delta 13 C$ and $\delta 180$ fractionation in aragonitic otoliths of marine fish. Geochim. Cosmochim. Ac., 61, 2909-2919.

Thorrold S.R., Latkoczy C., Swart P.K. and Jones C.M., 2001. Natal homing in a marine fish metapopulation. Science, 291, 297-299. 
Tohse H. and Mugiya Y., 2002. Diel variations in carbonate incorporation into otoliths in goldfish. J. Fish Biol., 61, 199-206.

Vander Zanden M.J. and Rasmussen J.B., 2001. Variation in delta N-15 and delta C-13 trophic fractionation: Implications for aquatic food web studies. Limnol. Oceanogr., 46, 2061-2066.

vanDijk P.L.M., Staaks G. and Hardewig I., 2002. The effect of fasting and refeeding on temperature preference, activity and growth of roach, Rutilus rutilus. Oecologia, 130, 496-504.

Vasek M., Kubecka J., Cech M., Drastik V., Matena J., Mrkvicka T., Peterka J. and Prchalova M., 2009. Diel variation in gillnet catches and vertical distribution of pelagic fishes in a stratified European reservoir. Fish Res., 96, 64-69.

Weidman C.R. and Miller R., 2000. High-resolution stable records from North Atlantic cod. Fish Res., 46, 327-342.

Werner E.E. and Gilliam J.F., 1984. The ontogenic niche and species interactions in size-structured populations. Ann. Rev. Ecol. Syst., 15, 393-425.

Winfield I.J., 1986. The influence of simulated aquatic macrophytes on the zooplankton consuption rate of juveniel roach, Rutilus rutilus, rudd, Scardinius erythrophthalmus, and perch, Perca fluviatilis. J. Fish Biol., 29, 37-48.

Wurster C.M. and Patterson W.P., 2003. Metabolic rate of late holocene freshwater fish : evidence from $\delta^{13} \mathrm{C}$ values of otoliths. Paleobiology, 29, 492-505.

Wurster C.M., Patterson W.P. and Cheatham M.M., 1999. Advances in micromilling techniques: A new apparatus for acquiring high-resolution oxygen and carbon stable isotope values and major/minor elemental ratios from accretionary carbonate. Comput. Geosci., 25, 1155-1162.

Wurster C.M., Patterson W.P., Stewart D.J., Bowlby J.N. and Stewart T.J., 2005. Thermal histories, stress, and metabolic rates of chinook salmon (Oncorhynchus tshawytscha) in Lake Ontario: evidence from intra-otolith stable isotope analyses. Can. J. Fish. Aquat. Sci., 62, 700-713.

Cite this article as: D. Gerdeaux and E. Dufour, 2015. Life history traits of the fish community in Lake Annecy: evidence from the stable isotope composition of otoliths . Knowl. Manag. Aquat. Ecosyst., $416,35$. 